\title{
UV Irradiation Accelerates Amyloid Precursor Protein (APP) Processing and Disrupts APP Axonal Transport
}

\author{
Angels Almenar-Queralt, ${ }^{1,5}$ Tomas L. Falzone, ${ }^{1}$ Zhouxin Shen, ${ }^{4}$ Concepcion Lillo, ${ }^{3}$ Rhiannon L. Killian, ${ }^{1}$ \\ Angela S. Arreola, ${ }^{1,5}$ Emily D. Niederst, ${ }^{1}$ Kheng S. Ng, ${ }^{1}$ Sonia N. Kim,,${ }^{1,5}$ Steven P. Briggs, ${ }^{4}$ David S. Williams, ${ }^{3}$ \\ and Lawrence S.B. Goldstein ${ }^{1,2,5}$ \\ ${ }^{1}$ Department of Cellular and Molecular Medicine, ${ }^{2}$ Department of Neurosciences, School of Medicine, ${ }^{3}$ Department of Pharmacology and Neurosciences, \\ and ${ }^{4}$ Section of Cell and Developmental Biology, Division of Biological Sciences, University of California, San Diego, La Jolla, California 92093 , and ${ }^{5}$ Sanford \\ Consortium for Regenerative Medicine, La Jolla, California 92037
}

Overexpression and/or abnormal cleavage of amyloid precursor protein (APP) are linked to Alzheimer's disease (AD) development and progression. However, the molecular mechanisms regulating cellular levels of APP or its processing, and the physiological and pathological consequences of altered processing are not well understood. Here, using mouse and human cells, we found that neuronal damage induced by UV irradiation leads to specific APP, APLP1, and APLP2 decline by accelerating their secretase-dependent processing. Pharmacological inhibition of endosomal/lysosomal activity partially protects UV-induced APP processing implying contribution of the endosomal and/or lysosomal compartments in this process. We found that a biological consequence of UV-induced $\gamma$-secretase processing of APP is impairment of APP axonal transport. To probe the functional consequences of impaired APP axonal transport, we isolated and analyzed presumptive APP-containing axonal transport vesicles from mouse cortical synaptosomes using electron microscopy, biochemical, and mass spectrometry analyses. We identified a population of morphologically heterogeneous organelles that contains APP, the secretase machinery, molecular motors, and previously proposed and new residents of APP vesicles. These possible cargoes are enriched in proteins whose dysfunction could contribute to neuronal malfunction and diseases of the nervous system including AD. Together, these results suggest that damage-induced APP processing might impair APP axonal transport, which could result in failure of synaptic maintenance and neuronal dysfunction.

Key words: amyloid precursor protein; APP axonal vesicles; axonal transport; gamma-secretase; kinesin; UV-irradiation

\section{Introduction}

Amyloid precursor protein (APP) and its proteolytic processing play a key role in the development of Alzheimer's disease (AD; Thinakaran and Koo, 2008; Zhang et al., 2012). Several lines of evidence suggest that APP and its proteolytic fragments partici-

Received April 8, 2013; revised Jan. 16, 2014; accepted Jan. 23, 2014.

Author contributions: A.A.-Q., R.L.K., S.P.B., D.S.W., and L.S.B.G. designed research; A.A.-Q., T.L.F., Z.S., C.L., A.S.A., E.D.N., K.S.N., and S.N.K. performed research; A.A.-Q., T.L.F., Z.S., and C.L. analyzed data; A.A.-Q. and L.S.B.G. wrote the paper.

This study was supported by the National Institute on Aging grant R01 AG032180. We thank Christine Vande Velde and Robert Vassar for providing the VDAC1 and BACE1 antibodies, respectively, and Laurent Taupenot for providing us with SH-SY5Y cells. We also thank Valeria Cavalli for technical expertise with synaptosome fractionations. We are grateful to Eddie Koo and David Kang for providing PSEN1/2 dKO MEFs and PSEN1/2 dKO rescued with PSEN1/2. We also thank Ivan Garcia-Bassets for providing LN-CaP cells and advice with GREAT analysis. We also thank Sol Reyna for her advice on statistical analysis. Finally, we thank Anthony H. Nguyen and Nisha Parmeswar for technical assistance.

The authors declare no competing financial interests.

Correspondence should be addressed to Lawrence S.B. Goldstein, Sanford Consortium for Regenerative Medicine, 2880 Torrey Pines Scenic Drive, La Jolla, CA 92037. E-mail: Igoldstein@ucsd.edu.

C. Lilo's present address: Instituto de Neurociencias de Castilla y León, 37007 Salamanca, Spain.

T. L. Falzone's present address: Instituto de Biología Celulary Neurociencias, CONICET, Facultad de Medicina, UBA, 1917 Buenos Aires, Argentina.

D. S. Williams' present address: Departments of Ophthalmology and Neurosciences, Jules Stein Eye Institute, UCLA, Los Angeles, California 90095.

DOI:10.1523/JNEUROSCI.1503-13.2014

Copyright $\odot 2014$ the authors $\quad 0270-6474 / 14 / 343320-20 \$ 15.00 / 0$ pate in signaling, axonal transport of vesicles, and synaptic formation and maintenance (Thinakaran and Koo, 2008; Brunholz et al., 2012; Zhang et al., 2012). Whether these roles of APP and its fragments are related to the development of $\mathrm{AD}$ is unknown.

In non-neuronal cells, amyloidogenic processing of APP is primarily endocytic, in part because $\beta$-site APP-cleaving enzyme 1 (BACE1) and $\gamma$-secretase may be most active in endocytic compartments (Koo and Squazzo, 1994). The site(s) of processing of APP in neurons is less clear. Previous studies suggest that traumatic brain injury (TBI) induces generation and accumulation of amyloid $\beta(\mathrm{A} \beta)$ peptide in axons (Smith et al., 2003; Chen et al., 2004). Although APP packed into axonal vesicles undergo kinesin1-dependent anterograde movement along microtubules in axons (Amaratunga et al., 1995; Kaether et al., 2000; Reis et al., 2012), little is known about the composition of actively transported APP axonal vesicle(s). Previous studies reported that at least some APP axonal vesicles contain components of the secretase processing machinery (Kamal et al., 2001; Szodorai et al., 2009; Steuble et al., 2012). These findings led to the idea that APP might regulate its own processing, and therefore, its own transport by cotransporting the secretase machinery.

The precise role of APP in the axonal transport of APPcontaining vesicles has been controversial (Brunholz et al., 2012). Biochemical evidence from several groups suggests that the short 
cytoplasmic region of APP links APP axonal vesicles to kinesin-1 directly, or indirectly via a ternary complex of APP, kinesin light chain 1 (KLC1) and JNK Interacting Protein 1 (JIP1; Kamal et al., 2000; Inomata et al., 2003; Matsuda et al., 2003). However, while some experiments suggest that the short cytoplasmic end of APP is necessary and sufficient for APP axonal transport (Gunawardena and Goldstein, 2001; Satpute-Krishnan et al., 2006), others suggest that APP lacking its C-terminal domain can still be transported along axons (Tienari et al., 1996; Rusu et al., 2007). It is possible that differences in expression levels may account for the different results (Goldstein, 2012). Recent work also suggests that APP axonal transport behavior can be altered by modulating secretase-dependent processing of APP, independent of A $\beta$ production (Rodrigues et al., 2012).

Here we test a key prediction of the hypothesis that APP mediates its own transport by taking advantage of a newly discovered damage response pathway that induces rapid, secretasemediated reduction of APP levels following exposure to UV. We also use new methods to reinvestigate the content of APP axonal vesicles. In addition to confirming our previous work that reported BACE1 and $\gamma$-secretase components in APP axonal vesicles, we also defined new components of APP vesicles whose altered delivery to synapses might play an important role in synaptic maintenance in neurodegenerative disease.

\section{Materials and Methods}

Antibodies and reagents. Anti-APP N terminus anti-TrkA (Millipore), Anti-APP C terminus; and anti-Pen2 (Zymed), anti-tubulin (DM1A; Sigma), anti-P-JNK (Cell Signaling Technology), anti-BACE1 (Affinity BioReagents or antibody generously provided by Dr. Vassar), and antiNicastrin (Affinity BioReagents); anti-presenilin 1 (PSEN1) and antiactin (Millipore Bioscience Research Reagents); anti-PSEN2 (Cell Signaling Technology), anti-APP C terminus, anti-APP like protein 1 (APLP1), and anti-APLP2 (Calbiochem); anti-ErbB4 and anti-dynein heavy chain (DHC; Santa Cruz Biotechnology), anti-GFP (JL-8; Clontech), anti-myelin basic protein (MBP; Dako), anti- $\mathrm{Na}^{+} / \mathrm{K}^{+}$ATPase (Millipore Biotechnology), anti-voltage-dependent anion channel 1 (VDAC1; Calbiochem), anti-GM130, anti-JNK1/2, and anti-N-cadherin (BD Biosciences); anti-Rab5 (Synaptic Systems), anti-kinesin heavy chain (KHC), anti-kinesin light chain (KLC), and anti-GAP43 (Millipore Bioscience Research Reagents); and anti-calnexin, anti-synapsin 1, antiVAMP, anti-SNAP25, anti-synaptophysin, and anti-synaptotagmin (StressGen). Goat anti-rabbit and rabbit anti-mouse used to coat Dynabeads were purchased from BioDesign. Dynasore, retinoic acid (RA), and cycloheximide were purchased from Sigma; MG132 and Compound E from Calbiochem; and $\mathrm{NH}_{4} \mathrm{Cl}$ from Fisher.

Mice, cell culture, and treatments. App-/- mice (Kamal et al., 2001) were backcrossed into C57BL/6J for multiple generations and then kept breeding as an $A p p-/-$ colony. Female $A p p-/-$ and retired C57BL/6J breeders were used for biochemical preparations. SH-SY5Y was cultured in 50\% Advanced MEM, 50\% F12 (Gibco), 10\% fetal bovine serum (FBS; Cellgro), and $10 \mu \mathrm{g} / \mathrm{ml}$ Penicillin/Streptomycin (P/S; Gibco). SH-SY5Y cells were induced to differentiate by adding RA at $25 \mu \mathrm{M}$ for $10 \mathrm{~d}$ changing media/RA every 3-4 d. Mouse embryonic fibroblasts (MEFs) derived from Psen $1 / 2$ double knock-out ( $\mathrm{dKO}$ ) cells and Psen $1 / 2 \mathrm{dKO}$ cells rescued with hPSEN1/2 were previously described (Kang et al., 2005; Repetto et al., 2007) and cultured in DMEM (Gibco), 10\% FBS, and 10 $\mu \mathrm{g} / \mathrm{ml} \mathrm{P} / \mathrm{S}$. HeLa cells were cultured in DMEM, $10 \% \mathrm{FBS}$ and $10 \mu \mathrm{g} / \mathrm{ml}$ $\mathrm{P} / \mathrm{S}$. Human fibroblasts derived from skin biopsies were cultured as previously described (Israel et al., 2012). LN-CaP cells were cultured in Advanced DMEM/F12 (Life Technologies) medium containing 10\% FBS (Omega Scientific). Mouse primary hippocampal cultures were prepared and maintained as previously described (Falzone et al., 2009). To UVirradiate cells, media was removed and uncovered cells were exposed to different UV doses using a UV-Stratalinker 1800 or 2400 (Stratagene). Media was added back to cells and cells were placed back to the incubator for indicated recovery times. For drug treatments, cells were incubated with Compound E (1 $\mu \mathrm{M})$, MG132 $(20 \mu \mathrm{M})$, cycloheximide $(50 \mu \mathrm{g} / \mathrm{ml})$, or dimethylsulfoxide (DMSO) as vehicle control for indicated times. For UV experiments cells were incubated with a corresponding drug for $1 \mathrm{~h}$ before exposing cells to UV irradiation and the drug was maintained during recovery time after UV exposure. For experiments inhibiting lysosomal and endosomal activity, cells were treated with $\mathrm{NH}_{4} \mathrm{Cl}(50 \mathrm{~mm})$ for $1 \mathrm{~h}$ or $4 \mathrm{~h}$ or with Dynasore $(100 \mu \mathrm{M})$ for $4 \mathrm{~h}$ before UV irradiation. $\mathrm{NH}_{4} \mathrm{Cl}$ or Dynasore was maintained during recovery time after UV exposure.

Plasmid constructs. pcDNA3 containing human APP $\alpha$-C terminal fragments (CTF; C83) and $\beta$-CTF (C99) were constructed following standard molecular cloning techniques. Corresponding DNA fragments were amplified by PCR using pcDNA-APP-YFP (Kaether et al., 2000) as a template using the following $5^{\prime}$ primers introducing an EcoRV site and a Kozak consensus sequence: 5' GCGCGATATCGCCACCATGTTGGTGTTCTTTGCAGAAGATG for C83, the primer 5' GCGCGATATCGCCACCATGGATGCAGAATTCCGACATG for C99, and the primer 3' GCGCGCGGCCGCCTAGTTCTGCATCTGCTCAAAG to introduce a NotI site after the stop codon.

Amplified products were purified, restriction digested with EcoRV and NotI, and ligated into pCDNA3 cut with EcoRV and NotI. Ligated plasmid was transformed and correct sequence was confirmed.

Immunoblots. After each treatment cells were rinsed with cold DPBS with protease (Calbiochem) and phosphatase inhibitors (Thermo Scientific). Cells were scraped in $0.5 \mathrm{ml}$ of DPBS/protease and phosphatase inhibitors, spun down at $4^{\circ} \mathrm{C} 1000 \times g_{A V}$ for $10 \mathrm{~min}$, and pellets were stored at $-80^{\circ} \mathrm{C}$ until use. Proteins were extracted in NP-40 lysis buffer (1\% NP40, $150 \mathrm{~mm} \mathrm{NaCl}, 50 \mathrm{~mm}$ Tris, $\mathrm{pH}$ 6.8) or using cell disruption buffer from PARIS kit (Ambion) following manufacturer's instructions. An equal amount of protein was loaded on $4-12 \%$ Bis-Tris gel (Invitrogen), transferred to nitrocellulose $0.2 \mu \mathrm{M}$ pore size (Whatman Protran) or PVDF of $0.45 \mu \mathrm{M}$ pore size (Immobilon-FL) or PVDF with a $0.2 \mu \mathrm{M}$ pore size (Bio-Rad). Membranes were blocked with either 5\% milk in TBS-Tween or Odyssey blocking buffer (LI-COR) for at least $30 \mathrm{~min}$ at room temperature and immunoblotted with corresponding primary antibodies followed by horseradish peroxidase-conjugated or infrared (IR)dye-conjugated secondary antibodies purchased from Zymed and LI-COR, respectively. Pierce ECL Western blotting substrate, SuperSignal West Dura extended duration substrate, or SuperSignal West Femto Maximum Sensitive substrate (Thermo Scientific) was used as needed to detect signal. IRdye immunoreactive bands were scanned and quantified using Odyssey infrared imaging system (LI-COR) following manufacturer's instructions.

Gene expression quantification. RNA was extracted using PARIS kit (Ambion) following manufacturer's instructions. RNA was DNase I digested (Ambion) for $1 \mathrm{~h}$ at $37^{\circ} \mathrm{C}$ to eliminate traces of genomic DNA. cDNA was made using First-strand cDNA kit (Invitrogen) using oligodT primers and following manufacturer's instructions. Real-time quantitative PCR (RT-qPCR) was performed on an Applied Biosystems 7300 RT PCR system using FastStart Universal SYBR Green Master (Roche). Primers for $A P P, A P L P 1$, and APLP2 and TBP mRNA were designed using primer3 (http://primer3.wi.mit.edu/) and checked for genomic cross-reactivity using the UCSC PCR webpage (http://genome.ucsc. edu). Single-band amplification for each primer was checked on a $1.2 \%$ agar/ethidium bromide gel. The following primers were used: 5'APP: GAGCTGCTTCAGAAAGAGCAA; 3'APP: TCAACAGGCTCAACTTC GTTT; 5'APLP1: CTTCCCACAGCCAGTAGATGA; 3'APLP1: CCAGGCATGCCAAAGTAAATA; 5'APLP2: CCATGGCACTGAATATGTGTG; 3'APLP2: CCTCATCATCCTCATCCACAG; 5' TBP: GAACCACGGC ACTGATTTTC; 3' TBP: CCCCACCATGTTCTGAATCT.

Movies and kymograph analysis. APP-YFP movement in mouse primary hippocampal cells was registered as previously described (Falzone and Stokin, 2012). Briefly, hippocampal cells maintained in culture for $10 \mathrm{~d}$ were transfected with pcDNA3 CMV-APP-YFP (Kaether et al., 2000) using Lipofectamine 2000 to achieve low transfection efficiency. Fifteen hours after transfection cells were treated with $1 \mu \mathrm{M} \gamma$-secretase inhibitor Compound $\mathrm{E}$ or equivalent volume of DMSO for $1 \mathrm{~h}$ before UV exposure. Four hours after, we registered APP-YFP axonal movement 
from coded coverslips. We selected isolated transfected axons and determined their directionality by either locating the cell body where they emanated from, or by locating their terminal growth cone. Cells were kept at $37^{\circ} \mathrm{C}$ using a heating stage and in $5 \% \mathrm{CO}_{2}$ chamber (Harvard Apparatus) and imaged under a $100 \times$ lens. Continuous 15 s stacks $(150$ frames) at a speed of 10 frames/s were collected on an inverted epifluorescent microscope (TE-2000U; Nikon) connected to a CoolSNAP $\mathrm{HQ}^{-}$ cooled CCD camera (Roper Scientific) using MetaMorph 7.0 (Universal Imaging). Kymographs were generated from stacked images and analyzed using MetaMorph as previously described (Falzone et al., 2009). Number of anterograde, retrograde, or total puncta per micron was calculated in Excel. Statistical differences between conditions were assessed using GraphPad Prism version 6 for Mac (GraphPad). We applied Kruskal-Wallis one-way analysis followed by Mann-Whitney $U$ test to determine specific differences between groups.

Biochemical fractionation. Synaptosomes from mice cortices were prepared basically as described by Abe et al. (2009). Briefly, cortices were separated from five mice brains and homogenized in 10 volumes of cold buffer B (0.32 м sucrose, 4 mm HEPES, pH 7.3, and protease inhibitors) in glass-Teflon homogenizer on a Stirrer LR-41/51 (Yamato Scientific America) at $512 \mathrm{rpm}$. The homogenate was centrifuged at $800 \times g_{A V}$ and the supernatant (S1) was centrifuged $15 \mathrm{~min}$ at $9200 \times g_{A V}$ to obtain the crude synaptosome pellet (P2). P2 was resuspended in $10 \mathrm{ml}$ of buffer B and recentrifuged $15 \mathrm{~min}$ at $9200 \times g_{A V}$ to obtain the washed crude synaptosome fraction (P2'). $\mathrm{P} 2^{\prime}$ was resuspended in $9 \mathrm{ml}$ of cold water and homogenized in a glass-Teflon to osmotically lyse the synaptosomes and immediately adjusted homogenate to $7.5 \mathrm{~mm} \mathrm{HEPES} / \mathrm{NaOH}, \mathrm{pH} 7.3$, and kept on ice for $30 \mathrm{~min}$. Homogenate was centrifuged at 25,000 $\times g_{A V}$ for $20 \mathrm{~min}$ to separate LP1 pellet enriched in presynaptic and postsynaptic membranes from the LS1 fraction enriched with synaptic vesicles. The LP2 fraction was obtained by sedimentation of LS1 on a $38 \%$ sucrose cushion for $2 \mathrm{~h}$ at $165,000 \times g_{A V}$. The floating fraction (LP2) was collected and diluted four times in HEPES $4 \mathrm{~mm}$. To help dispersion we homogenized diluted LP2 fraction by eight strokes using a 24 gauge syringe. The dispersed homogenate was layered onto a $10-38 \%$ continuous sucrose gradient and centrifuged at $65,000 \times g_{A V}$ for $4 \mathrm{~h}$ (Beckman SW41). One milliliter fractions were collected from top to bottom. Fractions 3 and 4 enriched in synaptic vesicles, and fractions $7-10$ enriched in larger organelles were pooled and named small or large vesicle pool (SVP or LVP), respectively, and quickly frozen in liquid nitrogen or continued with immunoisolation protocol.

Immunoisolations. Tosyl chloride activated M500 or M450 Dynabeads (Dynal Biotech/Invitrogen) were coated with purified goat anti-rabbit or anti-mouse following manufacturer's instructions. Beads were washed in binding buffer (PBS bovine serum albumin (BSA), 0.1\%, 2 mм EDTA) and incubated with specific or control primary antibody overnight at $4^{\circ} \mathrm{C}$. Beads were washed three times with PBS/BSA and incubated with 10 and $100 \mu \mathrm{g}$ of pooled 3-4 fraction (SVP) or 7-10 fractions (LVP), respectively. SVP or LVP collected directly from the gradient were diluted in 5 volumes of PBS/BSA and incubated with coated magnetic beads $4 \mathrm{~h}$ or overnight at $4^{\circ} \mathrm{C}$ on a rotating wheel. Beads were washed twice for 10 min with PBS/BSA and four times with PBS. Bound material was eluted by boiling beads in nonreducing sample buffer for $1 \mathrm{~min}$ and analyzed by Western blot, or eluted using RapiGest (Waters) to proceed to mass spectrometry (MS) analysis.

Electron microscopy analysis. Processing of SVP, LVP, and immunoisolated material attached to Dynabeads were analyzed by electron microscopy (EM) as previously described (Abe et al., 2009).

MS analysis. Automated 2D nanoflow LC-MS/MS analysis was performed using LTQ tandem mass spectrometer (Thermo Electron) using automated data-dependent acquisition. The detailed MS methods were described previously (Abe et al., 2009). Briefly, chromatographic separation was accomplished using an on-line 2D three-phase capillary column (RP1-SCX-RP2). Peptides were first eluted from RP1 column to SCX column using a $0-80 \%$ acetonitrile gradient for $150 \mathrm{~min}$. The peptides were fractionated by the SCX column using a series of six-step salt gradients $(0 \mathrm{~mm}, 30 \mathrm{~mm}, 60 \mathrm{~mm}, 100 \mathrm{~mm}$, and $1 \mathrm{~m}$ ammonium acetate for $20 \mathrm{~min}$ ) followed by high-resolution reverse phase separation using an acetonitrile gradient of $0-80 \%$ for $120 \mathrm{~min}$. The full MS scan range of
$300-2000 \mathrm{~m} / \mathrm{z}$ was divided into three smaller scan ranges (300-800, $800-1100$, and 1100-2000 Da) to improve the dynamic range. Each MS scan was followed by four MS/MS scans of the most intense ions from the parent MS scan. Approximately 100,000 MS/MS spectra were collected for each sample. Raw data were extracted and searched using Spectrum Mill (Agilent Technologies, version A.03.02). MS/MS spectra with a sequence tag length of 1 or less were considered as poor spectra and discarded. The rest of the MS/MS spectra were searched against the International Protein Index database limited to mouse taxonomy (version $3.14,68,632$ protein sequences). The enzyme parameter was limited to full tryptic peptides with a maximum miscleavage of 1 . All other search parameters were set to the Spectrum Mill default settings (carbamidomethylation of cysteines, $\pm 2.5 \mathrm{Da}$ for precursor ions, $\pm 0.7 \mathrm{Da}$ for fragment ions, and a minimum matched peak intensity of 50\%). Search results for individual spectra were automatically validated using the filtering criteria as previously reported (Abe et al., 2009). A concatenated forward-reverse database is used to calculate the in situ identification false discovery rates (FDRs). The total number of protein sequences in the combined database is 137,264 . Proteins that share common peptides were grouped to address the database redundancy issue. The proteins within the same group shared the same set or subset of unique peptides. A "group leader" heads protein groups that contain more than one protein accession number. The group leader is the protein with the highest identification score (the sum of the identification scores of the identified peptides composing the protein), which usually is the protein containing the largest number of peptides. In the remaining text, the term "protein" should be taken to mean "protein group leader." A total of 4347 protein sequences corresponding to 1021 protein groups were identified. The FDR is $0.12 \%$ (five false positive proteins from the reverse database). Spectra counting, i.e., number of MS/MS spectra detected for a particular protein, was used as a semiquantitative method to determine the presence of proteins in each sample. Each immunoisolation experiment was performed four times, and the total spectra count was used as a relative measure of protein abundance in each category. We used three criteria to filter the proteins in the final list as follows: (1) proteins have to be detected in at least two biological replicates, (2) proteins have at least two unique peptides, and (3) proteins have a minimum of a twofold increase in spectra counts relative to their respective control.

Gene ontology analysis. Functional annotation of vesicle components was obtained with freely available Genomic Regions Enrichment of Annotations Tool (GREAT; McLean et al., 2010). "Test regions" corresponded to a list of 5'-UTR sequences of genes encoding the components predicted by the mass-spec analysis of APP vesicles (this study) and syd vesicles (Abe et al., 2009). We used "Single nearest gene" (0.5 kb) association rules with the whole human genome as background. GREAT annotations and $p$ values for the two groups were downloaded, matched, and visualized with Microsoft Excel.

Statistical analysis. Statistical analysis was conducted with the GraphPad Prism version 6 for Mac (GraphPad). Analysis applied is specified in each corresponding figure legend.

\section{Results}

\section{UV irradiation decreases cellular content of APP but increases $A P P$ mRNA}

The underlying molecular mechanisms regulating neuronal APP levels and its processing are not completely understood. In particular, while there is evidence that neuronal damage may modify APP expression, effects of neuronal damage on APP processing are not well studied. Previously, a DNA damaging agent, camptothecin, was reported to decrease cellular APP content in several types of neuronal cells by reducing APP transcription (Cuesta et al., 2009b). We tested whether an alternative DNA damaging agent, UV radiation, causes a similar decline in full-length APP (APP FL). We found that UV exposure of human SH-SY5Y neuroblastoma cells led to a dose-dependent decrease in APP FL and also a decrease in APP CTFs (Fig. 1 A,B). Levels of another transmembrane protein, TrkA, were not significantly affected by UV 
A

UV dose $\left(\mathrm{mJ} / \mathrm{cm}^{2}\right)$ :

mock

$5 \mathrm{~mJ} / \mathrm{cm}^{2}$

$10 \mathrm{~mJ} / \mathrm{cm}^{2}$

$20 \mathrm{~mJ} / \mathrm{cm}^{2}$

$30 \mathrm{~mJ} / \mathrm{cm}^{2}$

Recovery time (Hours):
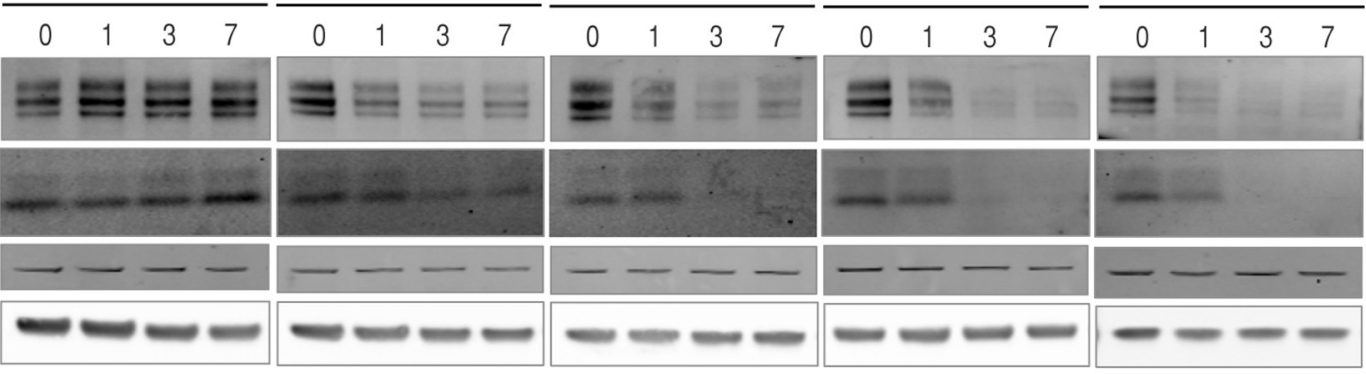

B
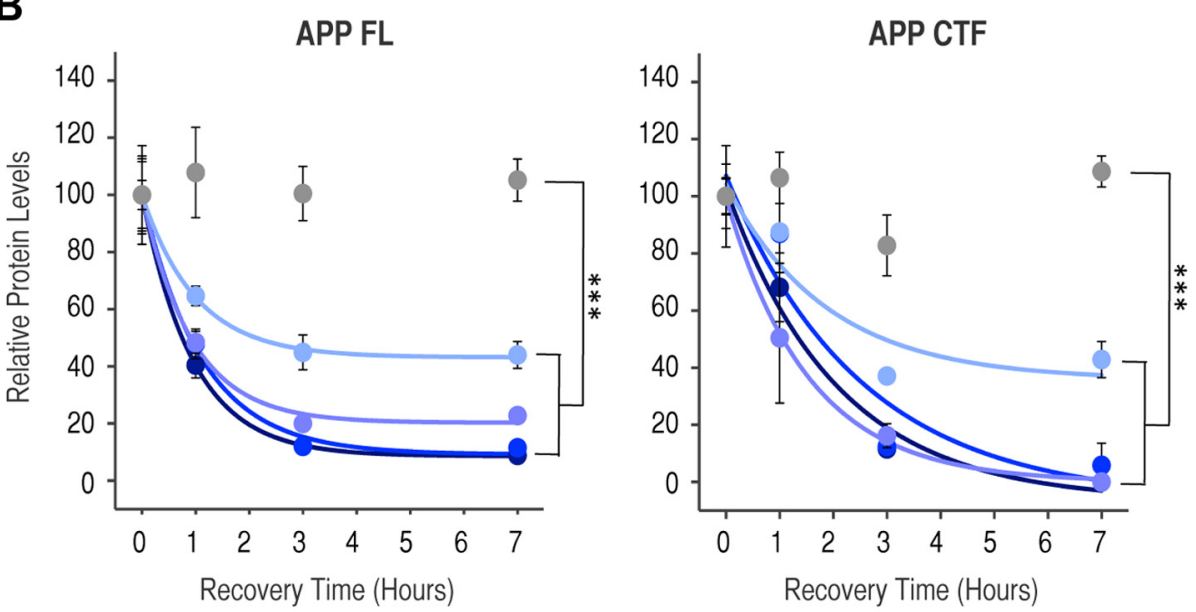

C

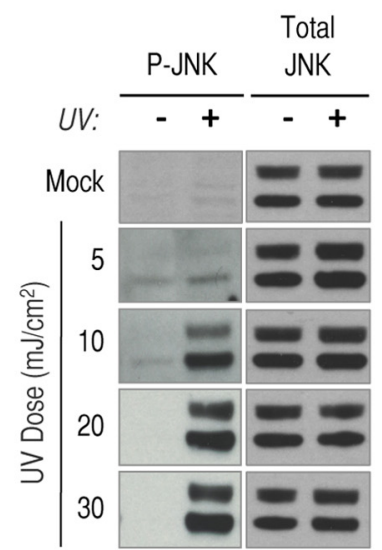

D

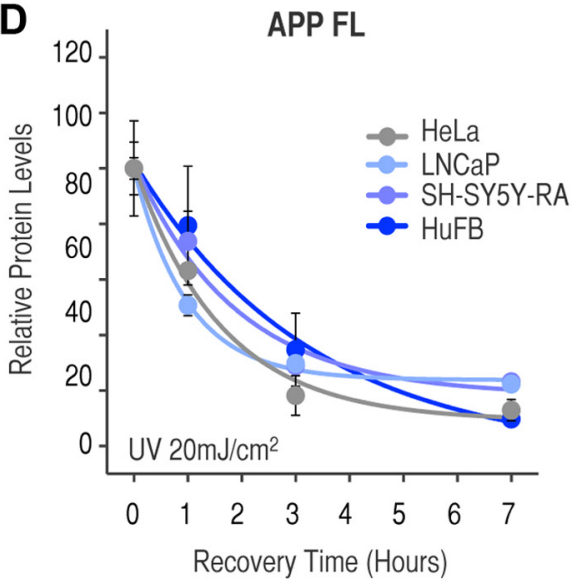

TrKA

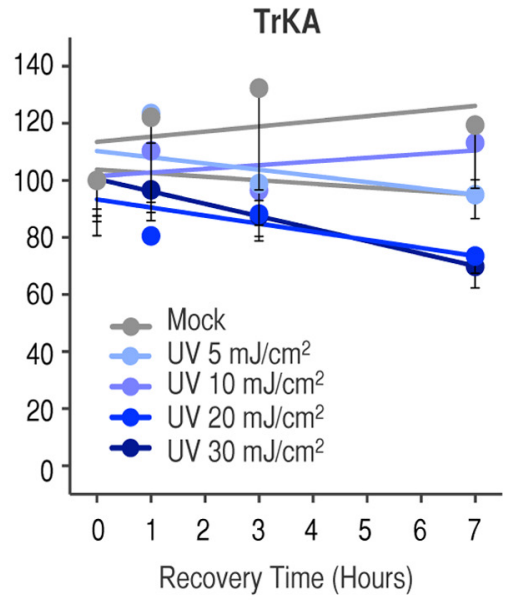

E

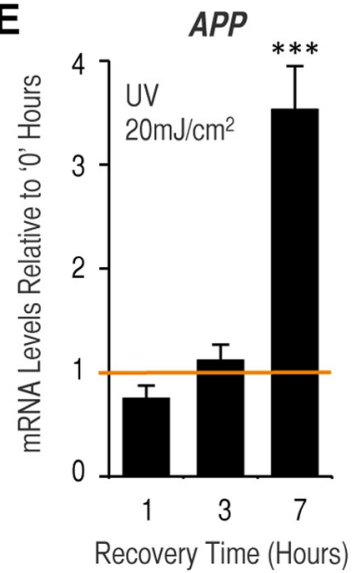

Figure 1. UV irradiation leads to a dose-dependent and differentiation state- and cell type-independent decline in APP protein. $A$, Human neuroblastoma SH-SY5Y cells were exposed with 0 - 30 $\mathrm{mJ} / \mathrm{cm}^{2} \mathrm{UV}$ radiation and left to recover for $0-7 \mathrm{~h}$. The same amount of protein from each condition was analyzed by Western blot to determine relative amounts of APP FL, APP CTFs, TrkA, and tubulin as loading control. B, Quantification of remaining levels of APP FL, APP CTFs, and TrkA at each time point after UV exposure normalized to tubulin from three different experiments as shown in $A$. Two-way ANOVA followed by Bonferroni post-test was applied, and statistics are shown only when significant. For representation purposes APP FL and APP CTF data points (except mock conditions) were fitted to a nonlinear exponential decay function with $R^{2}>0.8$, and TrkA data were fitted to a straight line with $R^{2}>0.8$. C, Human neuroblastoma SH-SY5Y cells were mock-irradiated or UV-irradiated at the indicated doses. Western blot shows levels of phosphorylated-c-Jun N-terminal kinase (P-JNK) and total JNK at time $0(-)$ and $1 \mathrm{~h}(+)$ after UV exposure. D, Quantification of detected APP FL protein by Western blot (data not shown) after $20 \mathrm{~mJ} / \mathrm{cm}^{2} \mathrm{UV}$ radiation in human epithelial HeLa cell line, human fibroblasts (HuFB) derived from skin biopsies, and LN-CaP prostate cancer cell line, and retinoic acid (RA)-differentiated SH-SY5Y cells (100\% = time 0$)$. E, TBP-normalized APP mRNA levels analyzed by RT-qPCR from SH-SY5Y cells exposed to UV $\left(20 \mathrm{~mJ} / \mathrm{cm}^{2}\right)$ and left to recover for the indicated times. Levels of mRNA from each time point are relative to corresponding times from mock-irradiated cells. Orange line represents levels of $\mathrm{mRNA}$ at time $=0(n=4$, mean \pm SEM $)$.

irradiation (Fig. 1 $A, B$ ) suggesting that UV-induced degradation is not a general behavior of transmembrane proteins. To verify one of the well established effects triggered by UV irradiation, we measured changes in protein phosphorylation of c-Jun NH2terminal kinase, JNK (i.e., JNK activation), which is a typical marker of cell stress (Ip and Davis, 1998). As expected, we ob- served a UV dose-dependent stimulation of JNK phosphorylation when compared with JNK1/2 total levels (Fig. 1C). To examine whether the UV-induced reduction in APP protein is cell state and cell type dependent, we tested and found similarly reduced APP levels following UV irradiation of RA-differentiated SH-S5Y5 cells, human epithelial HeLa cells and LNCaP cells, hu- 
man fibroblasts established from skin biopsies (Fig. 1D), and mouse neuroblastoma N2a cells (data not shown). In contrast to previous reports with camptothecin (Cuesta et al., 2009b), we found that the decrease in APP protein after UV irradiation (20 $\mathrm{mJ} / \mathrm{cm}^{2}$ ) did not correlate with decreases in APP mRNA. Instead, we observed increased APP mRNA following UV exposure when compared with mock-irradiated SH-SY5Y cells (Fig. 1E). These findings suggest that UV-induced reduction of APP is not a consequence of reduced APP mRNA levels. In support of a transcription-independent mechanism, levels of exogenously expressed APP tagged with YFP and driven by a CMV promoter instead of its endogenous promoter were also dramatically reduced after UV irradiation (see below; Fig. 5A, left). Together, these findings suggest that UV induces reduction of APP protein independently of cellular type, differentiation state, and APP transcription.

\section{UV irradiation accelerates secretase cleavage of APP family members}

Since UV irradiation induces increased levels of APP mRNA while reducing APP FL and APP CTF protein amounts, it is possible that UV irradiation inhibits APP translation, or alternatively, induces its processing. Indeed, previous reports suggest that DNA damage-inducing agents (i.e., camptothecin and etoposide) elicit $\gamma$-secretase activity (Jin et al., 2007, 2008; Minopoli et al., 2007). Normally, APP FL is first cleaved by either $\alpha$ - or $\beta$-secretase to generate $\alpha$ - and $\beta$-APP CTFs. Subsequently, APP CTFs can be further processed by $\gamma$-secretase generating the intracellular domain (AICD) and the small extracellular peptides $\mathrm{P} 3$ and $\mathrm{A} \beta$, respectively. Additionally, APP-CTFs can be also processed via a proteasome-dependent pathway (Skovronsky et al., 2000; Nunan et al., 2001). Either $\gamma$-secretase inhibition (Compound $\mathrm{E}$ ) or proteasome inhibition (MG132) in SH-SY5Y cells led to robust accumulation of APP CTFs (Fig. 2A), confirming that both mechanisms are capable of degrading APP CTFs under normal cellular conditions in this cell type. To determine the potential contribution of these pathways in reducing APP CTFs after UV exposure, we pretreated UV-irradiated SH-SY5Y cells with $\gamma$-secretase (Compound E) or proteasome (MG132) inhibitors. We found that pretreatment with the $\gamma$-secretase inhibitor, but not the proteasome inhibitor, protected APP CTFs against UV irradiation-induced reduction (Fig. 2B, first to third column). Furthermore, pretreatment with $\gamma$-secretase inhibitor not only prevented UV-induced APP CTF reduction but also resulted in accumulation of APP CTFs over time (Fig. 2B, third column, APP CTFs compare 0 versus $7 \mathrm{~h}$ lanes). This suggests that $A P P$ is still being translated after UV irradiation while being rapidly processed so there is no net accumulation of APP FL. In agreement with this view, simultaneous inhibition of $\gamma$-secretase and protein biosynthesis before UV irradiation does not result in APP CTF accumulation over time (Fig. 2B, fourth column, APP CTFs compare 0 vs $7 \mathrm{~h}$ ). The observed decline of $\beta$-CTF amount under these conditions is likely due to its cleavage by the still active $\alpha$-secretase activity (Fig. $2 B$, fourth column, APP CTFs compare 0 vs $7 \mathrm{~h}$ ). A rapid decline of APP FL is in agreement with the previously reported short half-life of cellular APP in other cell types (Weidemann et al., 1989). Accordingly, we found that APP FL and CTF levels are rapidly reduced when protein biosynthesis is inhibited in SH-SY5Y cells (Fig. 2C). To further test that $\gamma$-secretase activity is the major processing activity contributing to reduced levels of APP CTFs after UV exposure, we UV irradiated Psen $1 / 2 \mathrm{dKO}$ MEFs, which lack $\gamma$-secretase activity. We did not observe reduction of APP CTF levels in UV-treated Psen 1/2
dKO MEFs (Fig. 2D) while Psen $1 / 2$ dKO cells rescued with human PSEN1 and PSEN2 ( $+h P S E N 1 / 2)$ showed reduced APP CTF under the same UV-irradiation conditions (Fig. 2D). In both instances, levels of APP FL were reduced by UV exposure (Fig. $2 D$ ), suggesting that UV not only induces $\gamma$-secretase activity but also the preceding $\alpha$ - and/or $\beta$-secretase activities. Together, these results suggest that exposure to UV radiation accelerates secretase cleavage of APP CTF without inhibiting APP biosynthesis.

APP processing could be accelerated in a number of ways in response to UV irradiation. Secretase levels or activity could be upregulated, leading to a general increase in cleavage of substrates or alternatively, secretase activity may be increased specifically for APP. To gain insight into this question, we tested cellular levels of BACE1 and components of the $\gamma$-secretase complex (i.e., PSEN1, PSEN2, Nicastrin, and Pen2) in mock-irradiated or UVirradiated SH-SY5Y cells. While APP FL rapidly declines after UV exposure, relative levels of $\gamma$-secretase components were not significantly altered between mock- and UV-irradiated cultures and levels of BACE1 are slightly decreased (Fig. 3A), suggesting that $\mathrm{UV}$-induced acceleration of $\gamma$-secretase activity does not result from increases in the cellular content of secretase components.

The $\gamma$-secretase complex cleaves many other substrates in addition to APP (Haapasalo and Kovacs, 2011). To determine whether UV-induced APP $\gamma$-secretase cleavage is a generalized phenomenon among $\gamma$-secretase substrates we analyzed how the cellular content of other well known substrates behave after UV irradiation $\left(20 \mathrm{~mJ} / \mathrm{cm}^{2}\right)$. Interestingly, while cellular levels of ErbB4, or N-cadherin (N-cad) were unchanged following UV irradiation, levels of APP family members, APLP1 and APLP2, were reduced (Fig. $3 B$ ). Similar to APP mRNA, mRNA levels of $A P L P 1$ and $A P L P 2$ were significantly increased after UV irradiation (Fig. 3C) suggesting that the UV irradiation-induced APLP reductions are a result of changes occurring at the protein and not the transcriptional level. Protein biosynthesis inhibition also led to a rapid decline in fulllength APLP1 and APLP2 suggesting relatively short half-lives for the APP homologs (Fig. 3D), although the higher levels of APLP2 compared with APLP1 following treatment suggests its half-life may be longer than that of full-length APLP1 (Fig. $3 D)$. Such a difference in half-lives might explain the higher levels of APLP2 remaining after UV exposure when compared with APLP1 (Fig. 3B). Note that basal levels of APLP1 and APLP2 CTFs are barely detectable under basal conditions [Figure 3E, $(-1)$ lines]. To determine whether $\gamma$-secretase processing of APLP1 and APLP2 CTFs is induced by UV irradiation as we observed for APP CTF, we treated cells for $1 \mathrm{~h}$ with $\gamma$-secretase inhibitor (Compound E) alone or together with cycloheximide before exposure to UV irradiation. As we observed for APP CTFs, pretreatment with $\gamma$-secretase inhibitor before UV irradiation led to an accumulation of APLP1 and APLP2 CTFs over time that is precluded when simultaneously inhibiting $\gamma$-secretase activity and protein biosynthesis (Fig. $3 E$, compare 0 and $7 \mathrm{~h}$ lanes). Together these results suggest that UV radiation specifically accelerates secretase processing of APP family members and not other well known $\gamma$-secretase substrates.

\section{UV promotes accelerated APP processing via an endosomal/lysosomal pathway}

Multiple lines of evidence suggest that amyloidogenic processing of APP occurs mainly in endosomal/lysosomal cellular compartments (Koo and Squazzo, 1994; Yamazaki et al., 1996). In agree- 
A

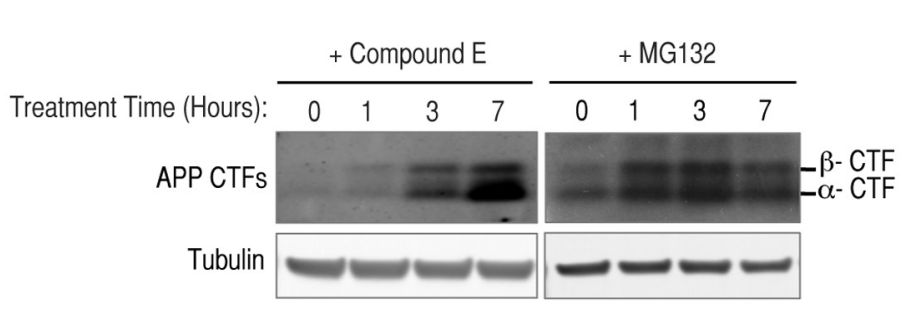

+ Compound $\mathrm{E}$

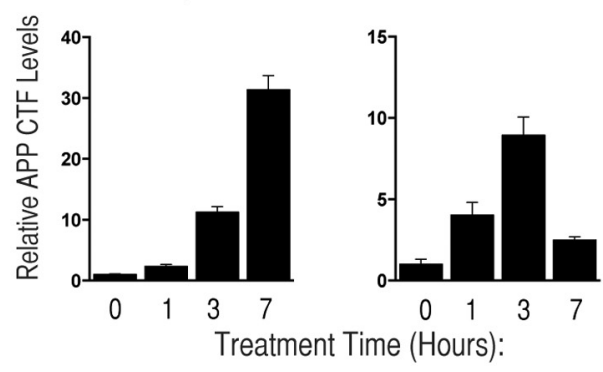

B

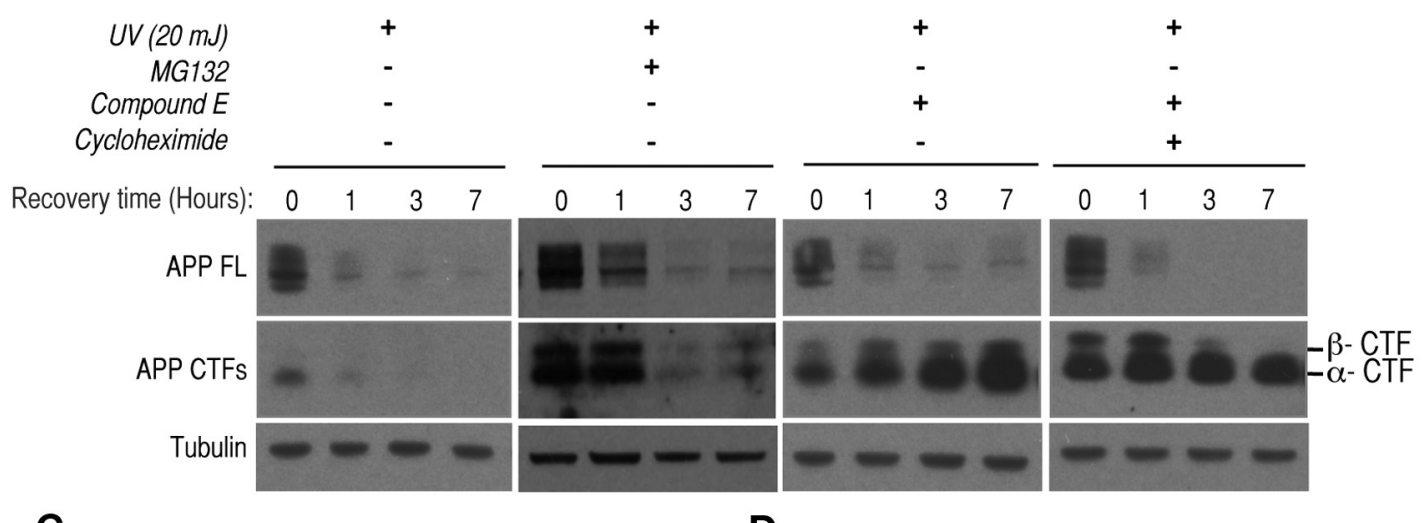

C

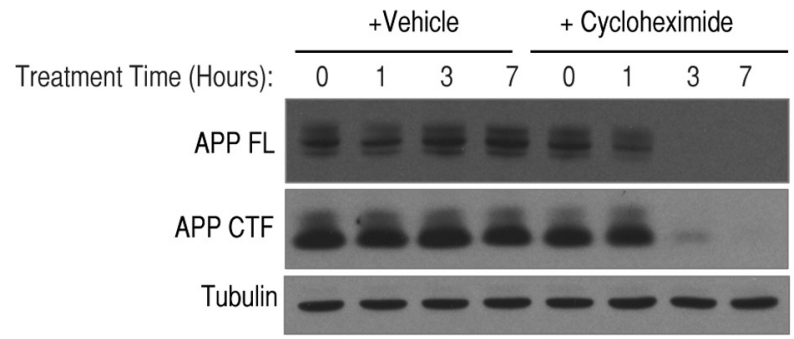

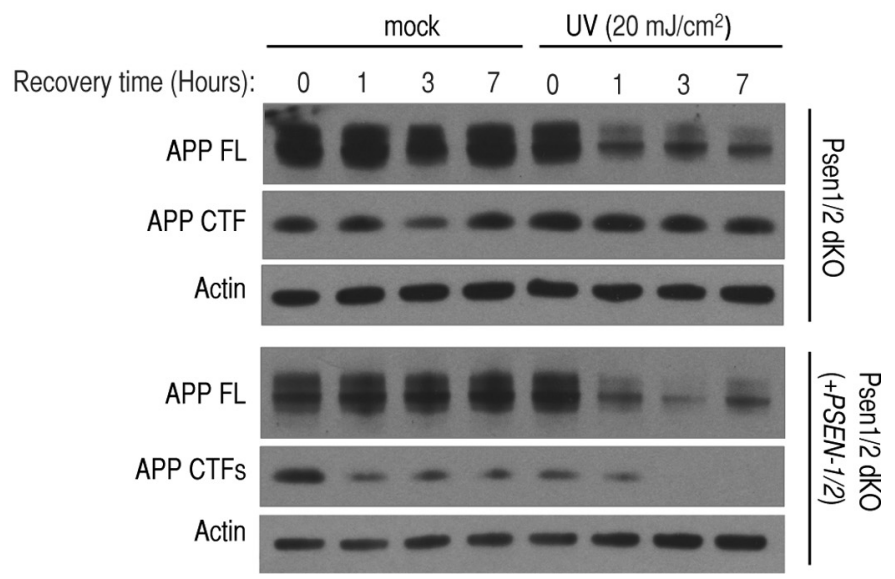

Figure 2. $\quad \gamma$-Secretase activity mediates UV-induced APP (TF decay. A, Left, Representative Western blot of SH-SY5Y cells treated with the $\gamma$-secretase inhibitor Compound E (1 $\mu$ M) or the proteasome inhibitor MG132 $(20 \mu \mathrm{M})$ for the indicated times and probed for APP CTFs and tubulin as loading control. Expected sizes for $\beta$-CTFs and $\alpha$-CTFs are marked on the right. Middle and right, Quantification of APP CTF remaining levels at each time point after each indicated drug treatment to tubulin from three different experiments as shown in $A$. B, SH-SY5Y cells were exposed to UV $\left(20 \mathrm{~mJ} / \mathrm{cm}^{2}\right)$ in the presence of vehicle (first column), MG132 (20 $\mu \mathrm{m}$; second column), Compound E (1 $\mu \mathrm{m}$; third column), or Compound E and cycloheximide $(50 \mu \mathrm{g} / \mathrm{ml})$ simultaneously (fourth column), and left to recover for the indicated times in the presence of indicated treatment. Equivalent amounts of protein were loaded and probed by Western blot for APP FL, APP CTFs, and tubulin as loading control. Expected sizes for $\beta$-CTFs and $\alpha$-CTFs are indicated on the right. C, Protein biosynthesis in SH-SY5Y cells was inhibited using cycloheximide $(50 \mu \mathrm{g} / \mathrm{ml})$ for the indicated times and analyzed by Western blot for APP FL, APP CTFs, and tubulin as a loading control. D, MEFs derived from Psen $1 / 2 \mathrm{dKO}$ (Psen $1 / 2$ dK0 cells; top three rows) or Psen $1 / 2 \mathrm{dKO}$ cells rescued with human PSEN1 and PSEN2 ( $+h P S E N 1 / 2$; bottom three rows) were mock-irradiated or UV-irradiated ( $20 \mathrm{~mJ} / \mathrm{cm}^{2}$ ) and analyzed by Western blots to probe for APP FL, APP CTFs, and actin as loading control.

ment, several reports show abnormal APP FL and CTF accumulation after treatment with lysosomotropic weak bases such as $\mathrm{NH}_{4} \mathrm{Cl}$ (Cole et al., 1989; Golde et al., 1992; Caporaso et al., 1994). To test whether interfering with the endosome/lysosome system affects APP processing induced by UV radiation, we pretreated cells with $\mathrm{NH}_{4} \mathrm{Cl}$ before UV exposure. As reported previously, $\mathrm{NH}_{4} \mathrm{Cl}$ treatment alone led to significant APP FL and APP CTFs accumulation (Fig. $4 \mathrm{~A}$, compare $3 \mathrm{~h}$ time points between control and $\mathrm{NH}_{4} \mathrm{Cl}$ columns under mock conditions). In control conditions, after 20 $\mathrm{mJ} / \mathrm{cm}^{2}$ of UV irradiation, most of APP FL ( 70-80\%) and APP
CTF ( $90 \%$ ) levels are dramatically reduced after $3 \mathrm{~h}$ (Fig. $4 A$, fourth column, $B$, gray bars). In contrast, in UV irradiated and $\mathrm{NH}_{4} \mathrm{Cl}$ pretreated cultures, APP FL and CTF levels were partially protected. Specifically, $\sim 50 \%$ more APP FL is present in $\mathrm{NH}_{4} \mathrm{Cl}$ pretreated cultures $1 \mathrm{~h}$ after UV exposure although no significant protection was observed after $3 \mathrm{~h}$ (Fig. $4 A$, compare fourth and fifth columns, $B$, left graph, red bars). As for APP CTFs, $\sim 30 \%$ more APP CTF is present $3 \mathrm{~h}$ after UV exposure when cells are pretreated with $\mathrm{NH}_{4} \mathrm{Cl}$ (Fig. $4 A$, compare fourth and fifth columns, $B$, right graph, red bars). To determine the potential contribution of endocytic 
A

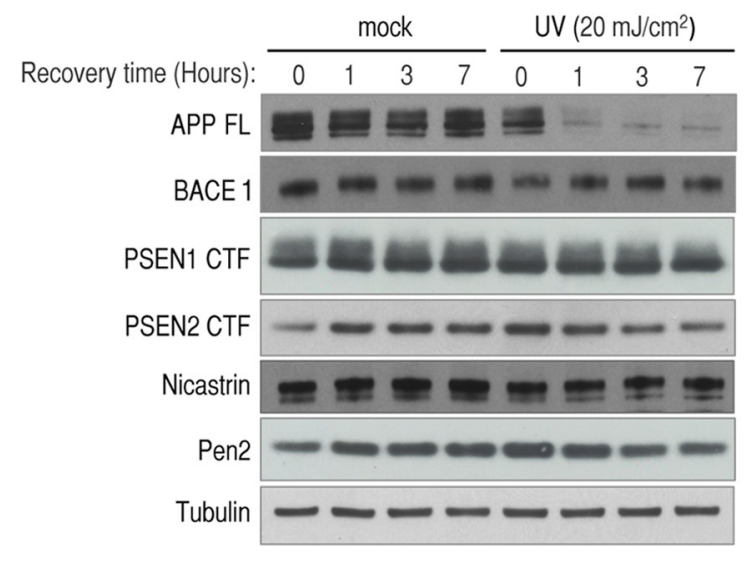

B
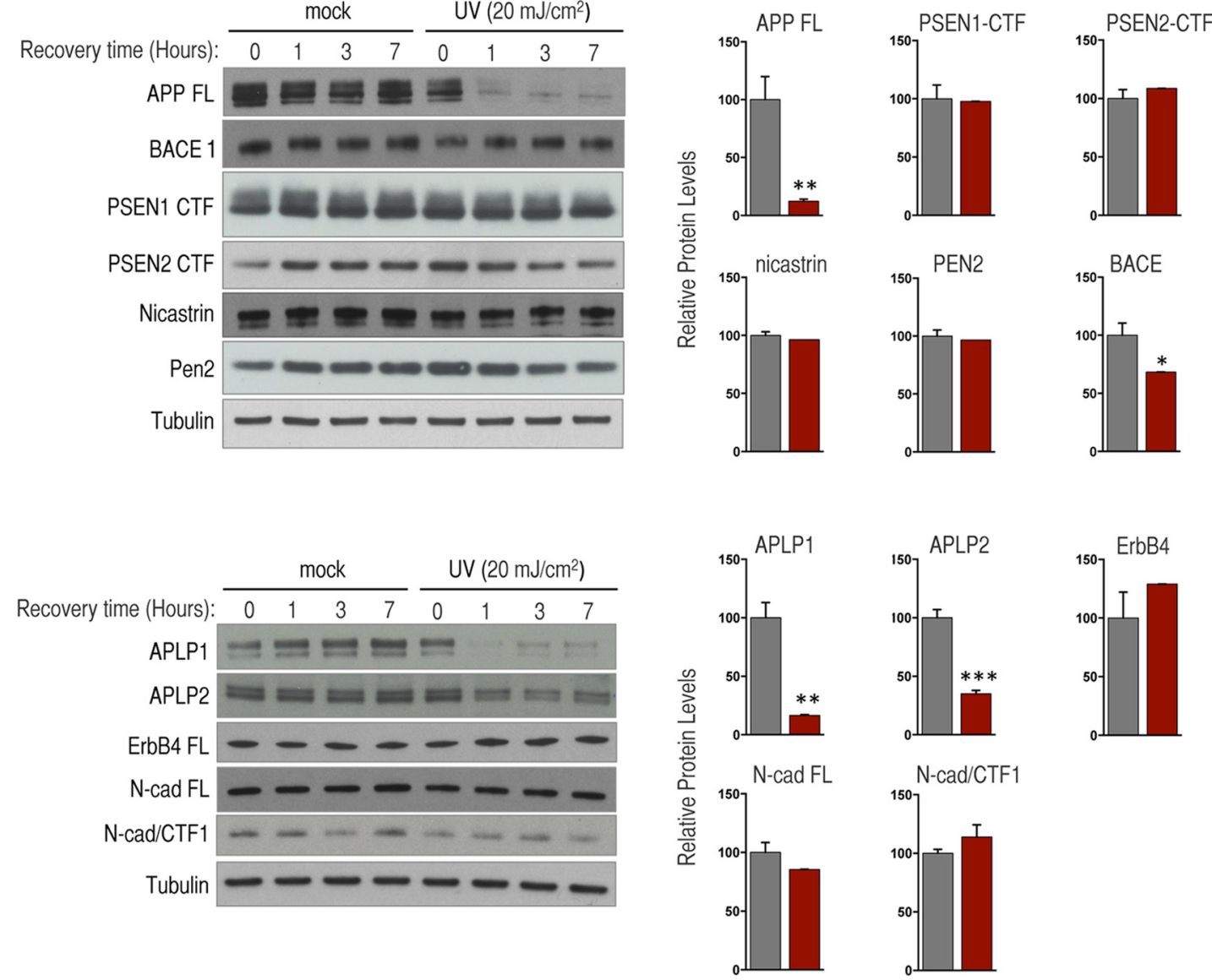

C
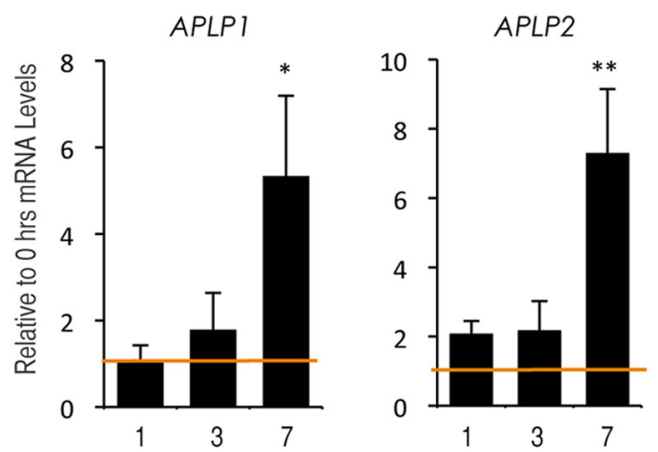

Recovery Time (Hours)

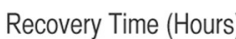

\section{D}

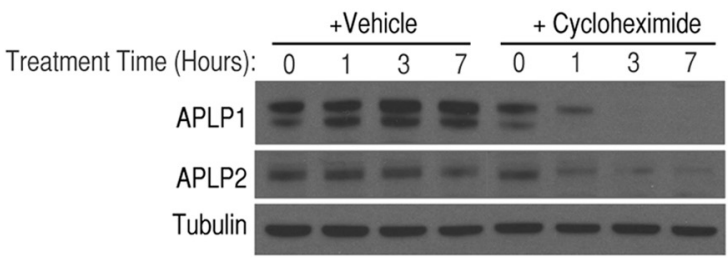

E

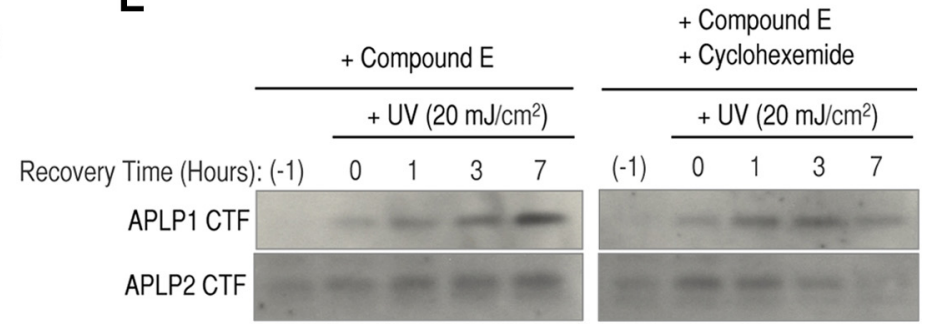

Figure 3. UV irradiation induces degradation of APLP1 and APLP2, but not other $\gamma$-secretase substrates. A, Equivalent protein amounts from SH-SY5Y cells mock-irradiated or UV-irradiated (20 $\mathrm{mJ} / \mathrm{cm}^{2}$ ) were analyzed by Western blots and probed for BACE1, PSEN1 CTF, and PSEN2 CTF, Nicastrin, Pen2, and tubulin as loading control. Graphs depict quantification of relative levels of indicated protein before UV exposure (gray bars) and seven hours after irradiation (red bars) from three different experiments as shown on left panels. B, We probed Western blot analysis of SH-SY5Y untreated or exposed to UV radiation $\left(20 \mathrm{~mJ} / \mathrm{cm}^{2}\right.$ ), allowed to recover for indicated times, for APLP1, APLP2, ErbB4, N-cad FL, N-cad CTF, Notch, and Tubulin as loading control. Graphs depict quantification of relative levels of indicated protein before UV exposure (gray bars) and seven hours after irradiation (red bars) from three different experiments as shown on left panels. C, TBP-normalized APLP1 and APLP2 mRNA levels analyzed by RT-qPCR from SH-SY5Y cells exposed to UV $\left(20 \mathrm{~mJ} / \mathrm{cm}^{2}\right)$ and relative to untreated cells (orange line represents levels of corresponding $\mathrm{mRNA}$ at time $=0$ ) and left to recover for indicated times $(n=3$, mean \pm SEM). $\boldsymbol{D}$, Protein biosynthesis in SH-SY5Y cells was inhibited using cycloheximide $(50 \mu \mathrm{g} / \mathrm{ml})$ for indicated times and samples were probed for APLP1 and APLP2 and tubulin as a loading control. E, SH-SY5Y cells treated for $1 \mathrm{~h}$ with Compound $\mathrm{E}(1 \mu \mathrm{M})$ alone or Compound $\mathrm{E}$ and cycloheximide were exposed to UV radiation and left to recover for the indicated times in the presence of indicated drugs. Levels of APP FL, APP CTFs, and tubulin as loading control were determined by Western blots. 
A

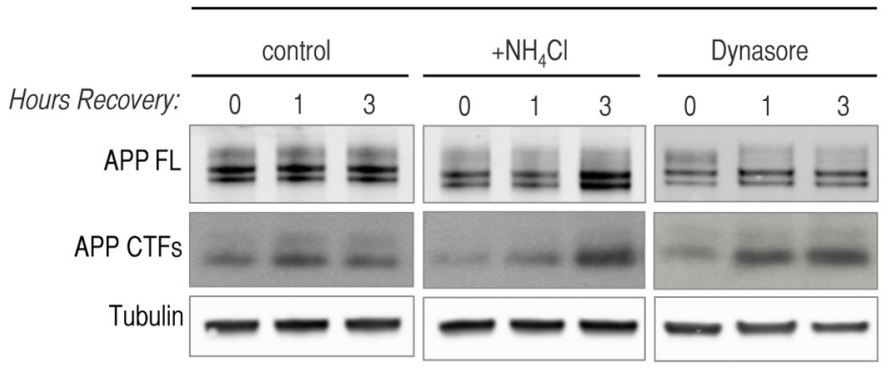

B

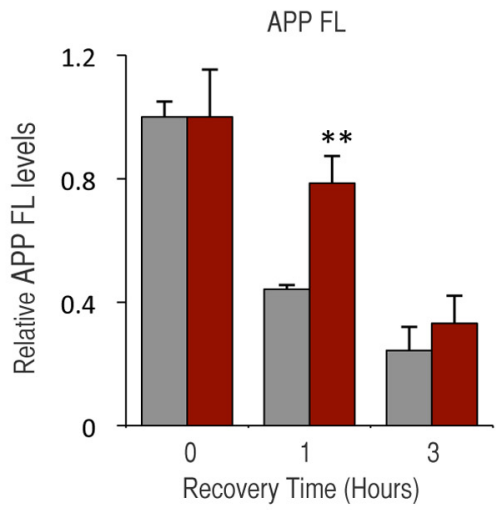

C

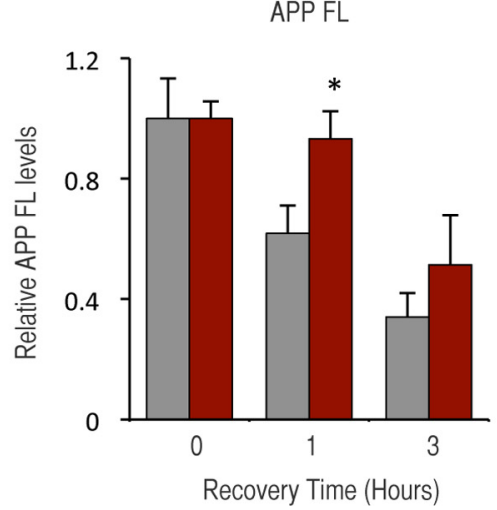

UV $\left(20 \mathrm{~mJ} / \mathrm{cm}^{2}\right)$
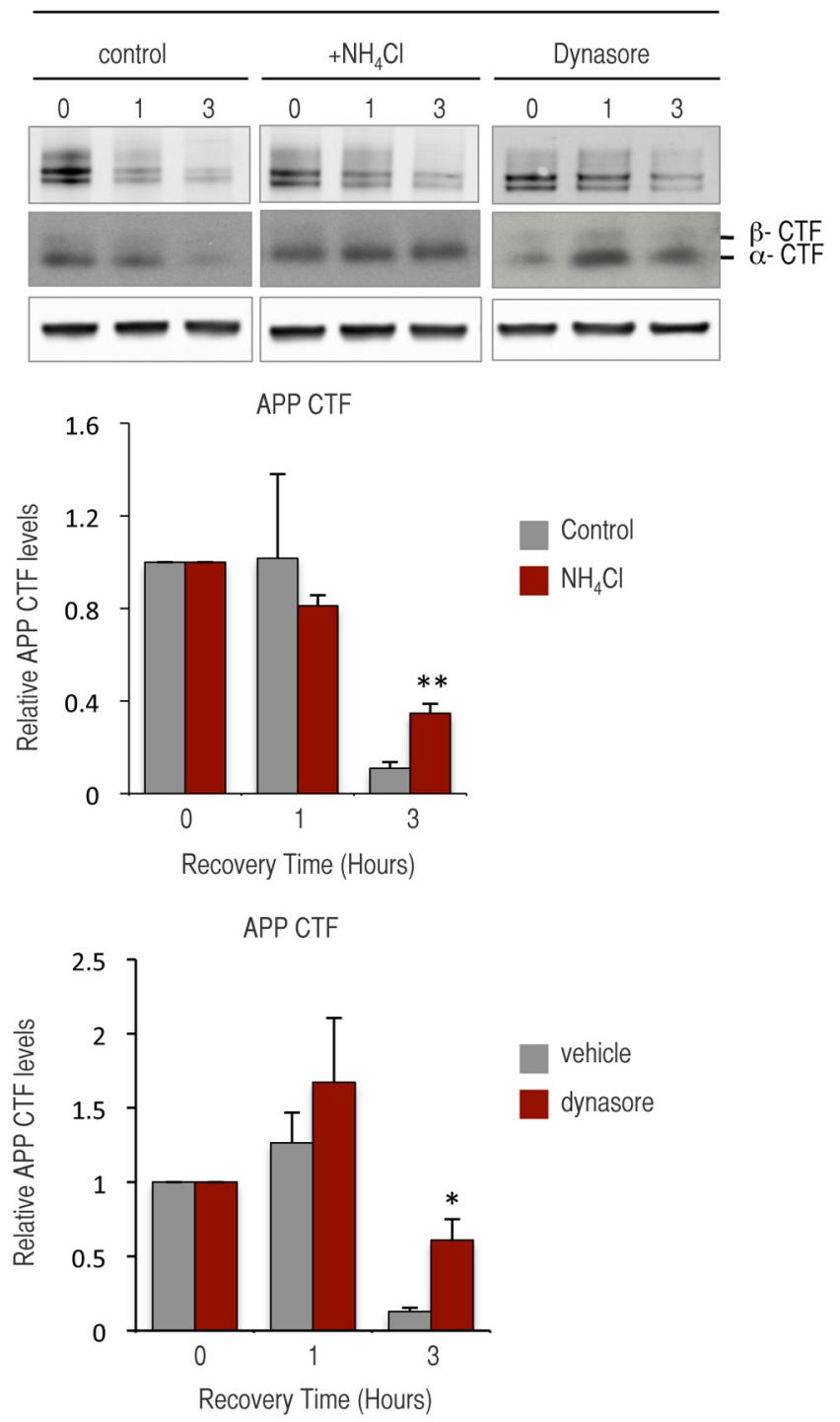

Figure 4. Endosomal/lysosomal pathways contribute to UV-induced APP processing. A, SH-SY5Y cells untreated (control), treated with NH ${ }_{4} \mathrm{Cl}(50 \mathrm{~mm})$ for 1 h or the endocytosis inhibitor Dynasore $(100 \mu \mathrm{M})$ for $4 \mathrm{~h}$ were mock or UV irradiated $\left(20 \mathrm{~mJ} / \mathrm{cm}^{2}\right)$ and left to recover for the indicated times. Corresponding drug was maintained in conditioned medium at all time points. Levels of APP FL and CTFs were analyzed by Western blot using tubulin as a loading control. $\boldsymbol{B}$, Graphs show the ratio of remaining APP FL and APP CTFs, each normalized to tubulin and to time $=0$, between samples exposed to UV and mock treated at each time point analyzed. Each treatment condition was similarly analyzed ( $n=3$, mean \pm SEM). C, Same as $\boldsymbol{B}$ but for Dynasore-treated cells. Experiments were performed four times ${ }^{*} p<0.05,{ }^{* *} p<0.01,{ }^{* * *} p<0.001$ by $t$ test at each time point comparing conditions.

pathways we used the cell-permeable inhibitor of dynamin, Dynasore (Macia et al., 2006). Dynasore treatment led to accumulation of APP CTF without altering levels of APP FL (Fig. 4A, compare first and third columns under mock conditions). Similarly to $\mathrm{NH}_{4} \mathrm{Cl}$, Dynasore compared with vehicle treatment had ( $30 \%)$ more APP FL $1 \mathrm{~h}$ after UV irradiation and $\sim 50 \%$ more APP CTF after $3 \mathrm{~h}$ (Fig. $4 A$, sixth column, $C$ ). These results suggest the possibility that trafficking of APP FL and APP CTF through endosomal/lysosomal pathways may contribute to UV-induced processing of APP.

\section{UV irradiation alters APP axonal transport in primary hippocampal cultures}

Numerous studies suggest that an interaction between the APP C-terminal domain and kinesin-1 motor proteins is required for proper axonal transport of APP-containing vesicles (Goldstein, 2012). One prediction from this model is that cleavage of membrane-associated APP CTF by $\gamma$-secretase will disrupt ax- onal transport of APP-containing vesicles by detaching them from kinesin-bound to microtubules. This disruption could occur either at the cell body interfering with the loading of APPcontaining vesicles onto microtubules, or along the axon resulting in a premature detachment of APP-containing vesicles from the kinesin/microtubule transport machinery (Kamal et al., 2001; Stokin and Goldstein, 2006). Our finding that UV irradiation accelerates $\gamma$-secretase cleavage of APP allows us to test this prediction. To visualize APP-containing vesicles under different conditions we used APP tagged with YFP at its C terminus (APPYFP) (Stokin et al., 2005; Falzone et al., 2009).

To determine whether APP-YFP behaves like endogenous APP when exposed to UV radiation we transfected SH-SY5Y cells with APP-YFP and exposed them to UV after pretreatment with vehicle or $\gamma$-secretase inhibitor (Compound $\mathrm{E}$ ). Like endogenous APP, cellular levels of APP FL (Fig. 5A, top) and APP CTF (Fig. $5 A$, middle) tagged with YFP declined rapidly after UV exposure. 
A
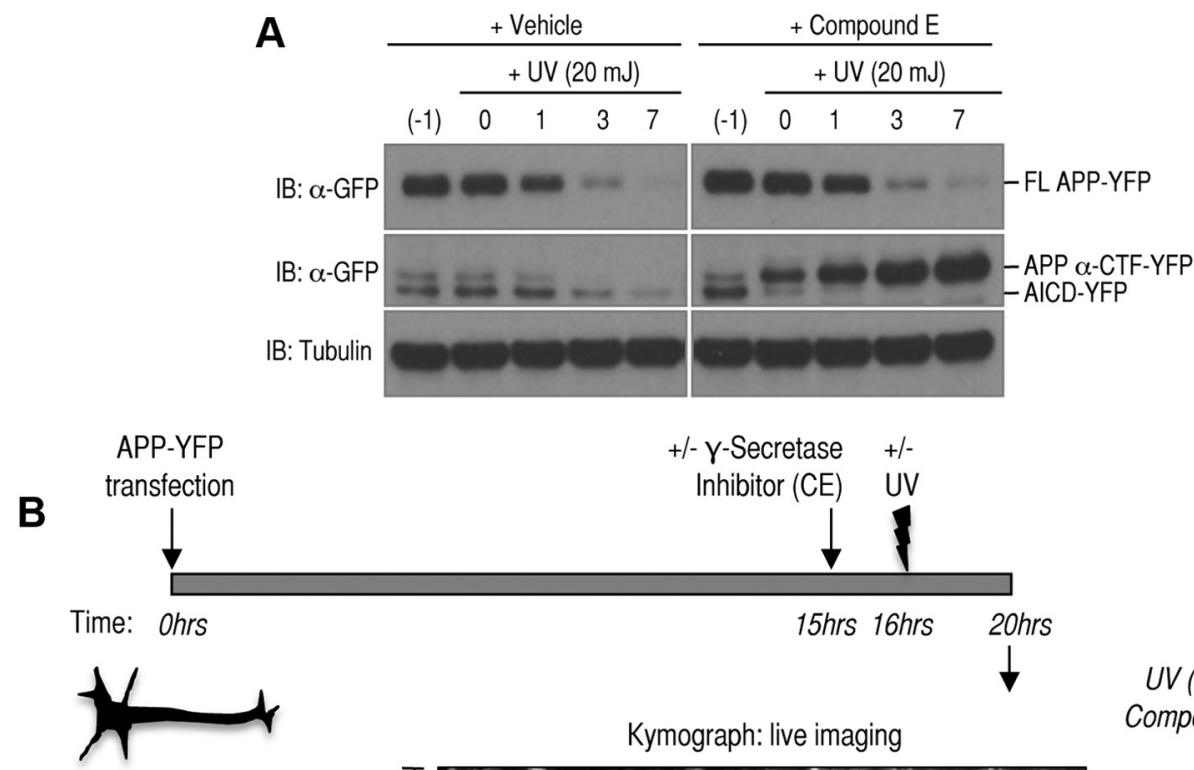

10 div Primary mouse hippocampal cultures
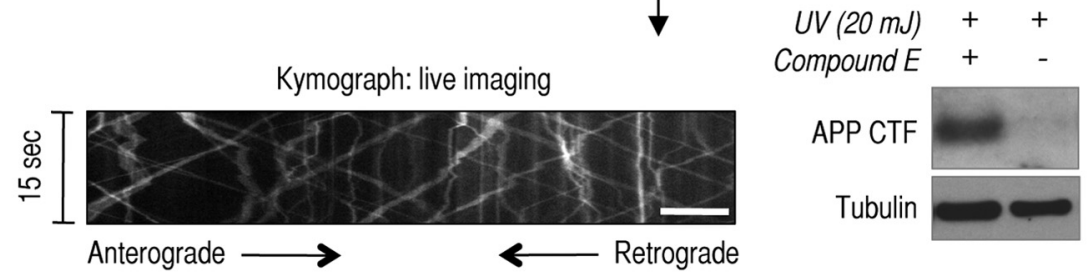

C
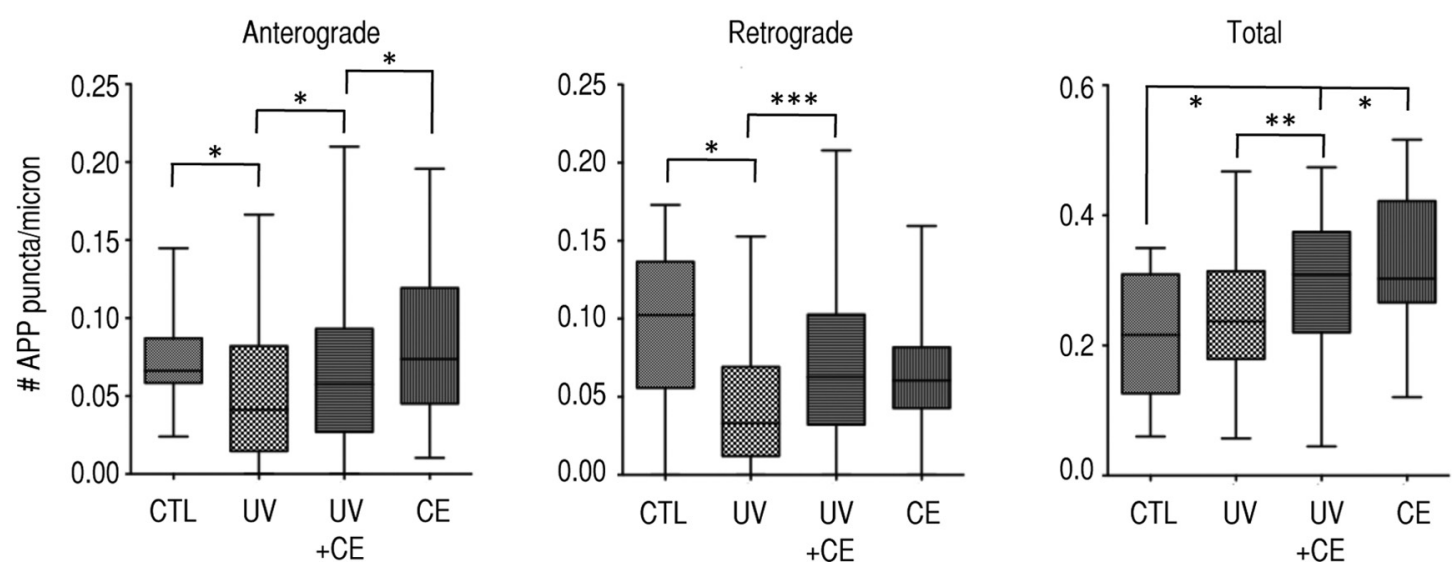

Figure 5. UV irradiation impairs APP axonal transport in primary mouse hippocampal cultures. A, To test whether transfected APP-YFP responds to UV, SH-SY5Y cells were transiently transfected with APP tagged with YFP at its (-terminal end (APP-YFP) and treated with vehicle or the $\gamma$-secretase inhibitor Compound E $(1 \mu \mathrm{m}) 1 \mathrm{~h}$ before UV $\left(20 \mathrm{~mJ} / \mathrm{cm}^{2}\right)$ exposure and left to recover for the indicated times in the presence of indicated drug treatment. Equivalent amounts of protein from each sample were analyzed by Western blots using GFP antibodies, which detect the YFP moiety. Full-length APP-YFP, $\alpha$-CTF-YFP, and AICD-YFP bands are indicated on the right. Tubulin was used as a loading control. $\boldsymbol{B}$, Scheme summarizing imaging experiment layout for hippocampal mouse neurons. Primary mouse hippocampal cells incubated $10 \mathrm{~d}$ in vitro (div) were transiently transfected with APP-YFP. Fifteen hours later the cells were treated with vehicle or $\gamma$-secretase inhibitor Compound E (CE; $1 \mu \mathrm{m})$ for $1 \mathrm{~h}$ before mock or UV radiation $\left(20 \mathrm{~mJ} / \mathrm{cm}^{2}\right)$. Following a $4 \mathrm{~h}$ recovery period, $15 \mathrm{~s}$ of APP-YFP movement was recorded per axon and the data transformed into kymographs displaying the trajectories of stationary, anterograde, and retrograde YFP-containing puncta. Kymograph displayed was obtained from APP-YFP transfected in control cells. Immediately after imaging, cells were processed for Western blot analysis to detect endogenous APP CTFs, and tubulin as loading control. C, Graph depicting the number of anterograde, retrograde, and total APP-YFP puncta/micrometer in control, UV irradiated $\left(20 \mathrm{~mJ} / \mathrm{cm}^{2}\right)$, CE treated, and UV irradiated $\left(20 \mathrm{~mJ} / \mathrm{cm}^{2}\right)$ after CE-treated hippocampal cultures. Horizontal lines within the column represent the median. The vertical lines (whiskers) mark the minimum and the maximum of all data points in each condition. The bottom and the top of the box mark the $25 \%$ percentile and $75 \%$ of all data, respectively $(n=3) ;{ }^{*} p<0.05,{ }^{* *} p<0.01,{ }^{* * *} p<0.001$ by Mann-Whitney $U$ test.

APP-YFP CTF UV-induced decline is efficiently prevented by inhibition of $\gamma$-secretase activity (Fig. 5A). Like endogenous APP, $\gamma$-secretase inhibition not only prevented APP CTF-YFP decline induced by UV radiation, but it also led to a robust accumulation of APP CTF-YFP over time (Fig. $5 \mathrm{~A}$ ), suggesting continuous biosynthesis of FL APP-YFP after UV exposure. Parallel experiments transfecting SH-SY5Y cells with the previously characterized APP $\beta$ CTF-EGFP (Rodrigues et al., 2012), followed by Western blots using GFP and APP C terminus antibodies, suggest that the upper and bottom bands we detect with the GFP antibodies are APP $\alpha$-CTF-YFP and AICD-YFP, respectively (data not shown).

We used APP-YFP to assess whether UV-induced $\gamma$-secretase cleavage alters the axonal transport of APP-containing vesicles in primary hippocampal cultures. Cultured mouse hippocampal neurons were transfected with APP-YFP and $15 \mathrm{~h}$ later treated with vehicle or $\gamma$-secretase inhibitor Compound $\mathrm{E}$ for $1 \mathrm{~h}$ before UV irradiation $\left(20 \mathrm{~mJ} / \mathrm{cm}^{2}\right)$ exposure and then left to recover for $4 \mathrm{~h}$ in the presence of vehicle or Compound $\mathrm{E}$ before recording 
APP-YFP transport along the axon (Fig. 5B). As reported previously, APP-YFP puncta are transported bidirectionally along the axons (Falzone et al., 2009; a representative kymograph is shown in Fig. 5B). Immediately after imaging, we processed samples for biochemistry and confirmed that inhibition of $\gamma$-secretase activity protects against UV-induced decline of endogenous APP CTFs in primary hippocampal cultures (Fig. 5B).

We found that after UV irradiation the number of moving anterograde and retrograde APP-YFP puncta/micrometer was significantly reduced (Fig. 5C, left and middle graph). Pretreatment with $\gamma$-secretase inhibitor before UV irradiation protected anterogradely and retrogradely transported APP-YFP puncta/ micrometer from UV-induced reduction (Fig. $5 C$ ). Despite the reduced number of moving APP-YFP puncta/micrometer, when counting all APP-YFP puncta including those that were stationary, UV irradiation did not alter the total number of APP-YFP puncta/micrometer (Fig. $5 C$, right graph). These results suggest that instead of reducing the number of APP vesicles entering the axon, UV might induce detachment of APP vesicles already present in the axon from the transport machinery leading to increased stationary puncta. Interestingly, treatment with $\gamma$-secretase inhibitor (Compound $\mathrm{E}$ ) alone did not significantly alter the number of APP-YFP puncta moving in the anterograde or retrograde direction (Fig. 5C, left and middle graph); however, it increased the total number of APP-YFP puncta in the axon (Fig. 5C, right graph). One potential explanation for this effect is that APP CTFs that accumulate because of $\gamma$-secretase inhibition might move slower than APP FL along the axon (Rodrigues et al., 2012). This effect could lead to an increase in the total number of puncta in the axon without altering the number of moving particles. Together, these findings agree with the possibility that $\gamma$-secretase activity induced by UV exposure might alter APP axonal transport by prematurely inducing its cleavage during transport.

\section{Evidence for a population of synaptosomal APP-containing vesicles that cosediment with motor proteins and secretases}

A prediction of the hypothesis that enhanced $\gamma$-secretase cleavage of APP interferes with kinesin-1-dependent axonal transport of APP-containing vesicles is that APP and its secretases might reside in the same vesicular compartment during axonal transport. In fact, accumulating evidence suggests that secretase components might be cotransported within APP-containing vesicles (Kamal et al., 2001; Szodorai et al., 2009; Steuble et al., 2012), although the details are controversial (Lazarov et al., 2005; Goldsbury et al., 2006; Szodorai et al., 2009; Steuble et al., 2012). Supporting the view that APP and its secretase machinery might share a vesicle in transit, it has been reported that APP may be proteolytically processed into several fragments including $A \beta$ during axonal transport (Amaratunga and Fine, 1995; Tokuda et al., 1996; Kamal et al., 2001; Smith et al., 2003; Stokin and Goldstein, 2006), and that endogenous APP, BACE1, and PSEN1 costain vesicular puncta in wild-type mouse sciatic nerves (Kamal et al., 2001). Additionally, accumulation of A $\beta$ over time can be induced from accumulation of APP after TBI (Smith et al., 2003; Chen et al., 2004). Other reports, however, suggest that APP proteolysis occurs in the cell body and that the various APP fragments can be sorted into separate vesicles before transport into the axon (Muresan et al., 2009).

We revisited this question using an independent approach by enriching for APP-containing vesicles from mouse cortical synaptosomes using APP antibodies conjugated to magnetic beads. In addition to being highly enriched in synaptic vesicles, synaptosomes also include APP-containing organelles as- sociated with Rab5 endosomal compartments, which are thought to be the initiating organelles for APP retrograde transport from axonal terminals (Ikin et al., 1996). Synaptosomes might also include kinesin-1-dependent anterograde transport organelles (Abe et al., 2009), and therefore, may provide a unique source of both anterograde and retrogradely transported APP vesicles.

We performed subcellular fractionation of mouse cortices as previously reported to isolate a synaptosome-enriched LP2 fraction (Huttner et al., 1983; Abe et al., 2009). As expected, the LP2 fraction was enriched for synaptotagmin, a synaptic vesicle component (Fig. 6A), while markers for plasma membrane $\mathrm{Na}^{+} / \mathrm{K}^{+}$ ATPase, the mitochondria resident protein VDAC, the MBP, and the Golgi marker GM130, were barely detectable (Fig. 6A). The presence of calnexin, cathepsin D, and Rab5 in the LP2 fraction indicates the presence of vesicle populations associated with endoplasmic reticulum, lysosomes, and endosomes, respectively (Fig. 6A). APP FL, although widely distributed among all the fractions, is abundant in the Golgi-enriched S2 fraction, the synaptic membrane-enriched fraction LP1, and the synaptosomal vesicle fraction LP2 as described previously (Fig. 6A; Ikin et al., 1996; Beher et al., 1999; Groemer et al., 2011). APP CTFs are highly enriched in both the synaptosomal vesicle fraction LP2 and the synaptic membrane-enriched fraction LP1 (Fig. 6A). The presence of APP FL and CTF in LP1 may be due to the proposed association of APP with the synaptic active zone (Volknandt and Karas, 2012). In agreement with the idea that APP must be fully glycosylated to reach the presynaptic terminus (Lyckman et al., 1998), the ratio between the top APP band-likely corresponding to $\mathrm{N}$ - or $\mathrm{O}$-glycosylated mature forms of APP-and the bottom band-likely corresponding to immature APP forms-is higher in the synaptic vesicle-enriched fraction LP2 than in the Golgienriched fraction S2 (Fig. 6A, compare levels of APP mat. to immat. band in S2 and LP2 lanes). These results suggest that most of the LP2-associated APP separated for further analysis is deenriched in Golgi-associated APP. Motor protein subunits KHC and KLC1, as well as BACE1, PSEN1, and other $\gamma$-secretase components (i.e., Pen2, Nicastrin) were also detected in the LP2 fraction (Fig. 6A).

Synaptosomes contain vesicles of different sizes including small ( $\sim 50 \mathrm{~nm}$; (Takamori et al., 2006) synaptic vesicles and larger Rab5-containing organelles (Ikin et al., 1996). Therefore, we separated vesicles based on their size by fractionating the LP2 fraction on continuous sucrose gradients as described previously (Abe et al., 2009). The synaptic vesicle marker VAMP is highly enriched in fractions $3-4$ (Fig. 6B) as expected based on the small size of bona fide synaptic vesicles (Takamori et al., 2006; Abe et al., 2009). We named fractions 3 and 4 the SVP (Abe et al., 2009; Fig. 6B). In contrast, Rab5, which is believed to be associated with small synaptic vesicles and larger endosomal organelles (Ikin et al., 1996), was enriched in SVP fractions 3-4 and also in fractions 7-10, which we termed LVP (Abe et al., 2009; Fig. 6B). EM analysis confirmed enrichment of small $(\sim 50 \mathrm{~nm})$ vesicles in fractions comprising SVP when compared with fractions comprising LVP containing larger membranous organelles (Fig. 6C). The bulk of APP FL and APP CTF fractionate in LVP although traces are detected in SVP fractions (Fig. 6B). A portion of the motor protein components KHC, KLC1, and DHC remain on top of the gradient (fractions 1-2), in fractions that contain soluble proteins (Fig. 6B). As motor proteins are noncovalently associated with vesicles and organelles, it is expected that at each fractionation step they can detach from membranes. Despite this 
A

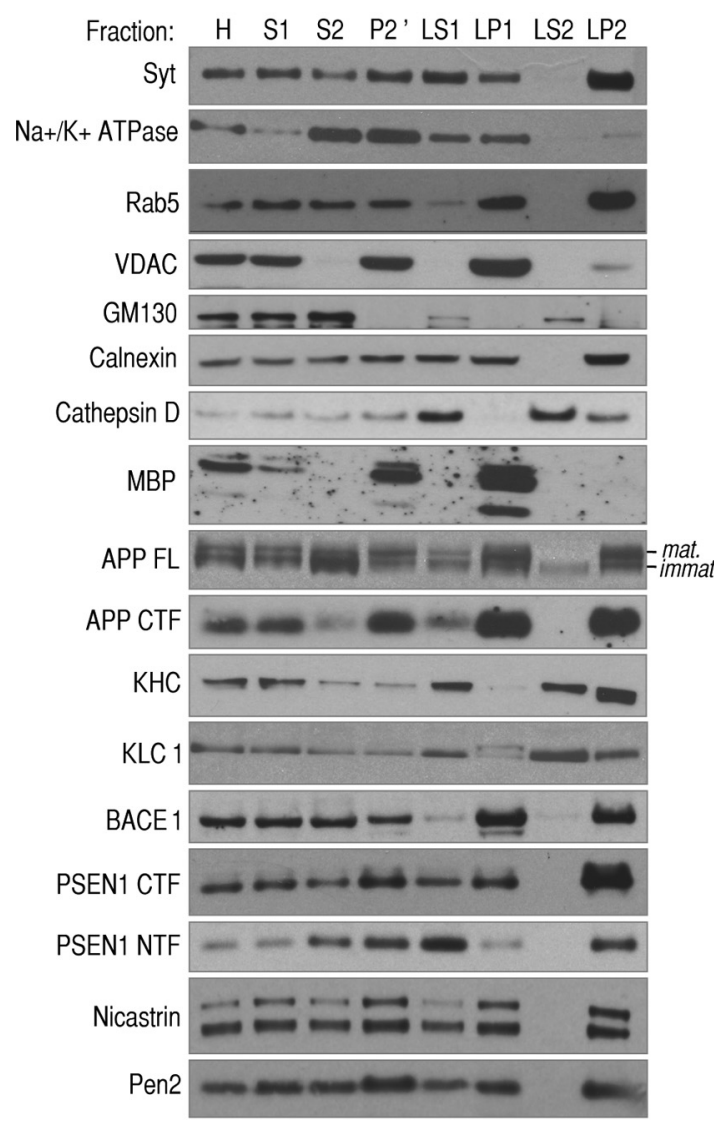

B

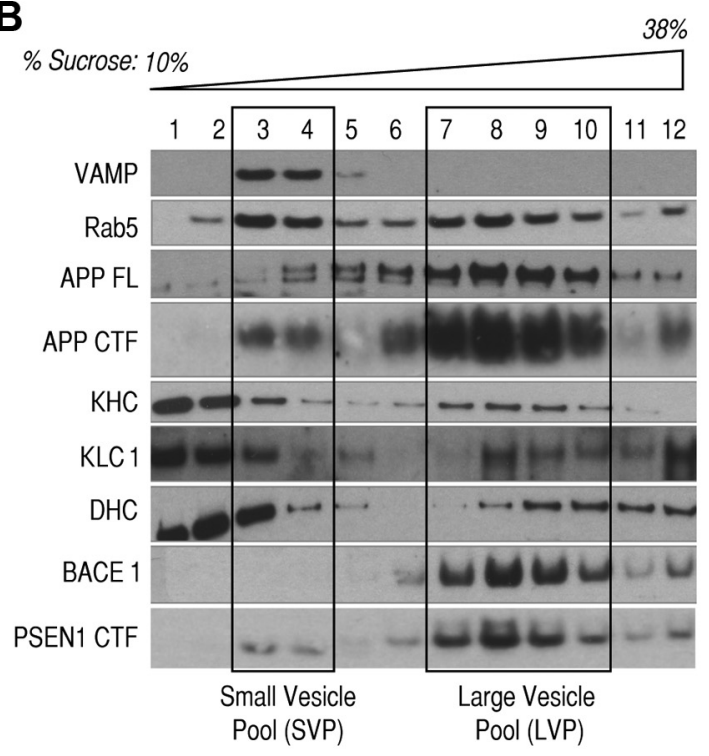

C
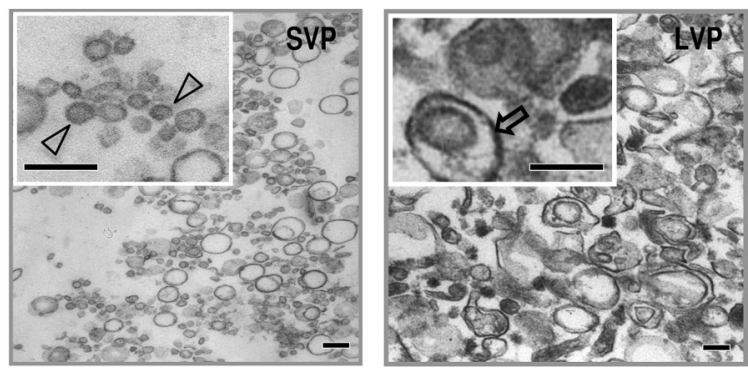

Figure 6. APP FL and APP CTF cofractionate with motor proteins and secretase components to LVPs in mouse synaptosomes. A, Mouse brain cortices were fractionated to obtain the synaptosomeenriched fraction LP2. The same amount of protein from each fraction was loaded and probed using antibodies to the proteins indicated on the left. $\boldsymbol{B}, \mathrm{LP2}$ fraction was sedimented on a continuous sucrose velocity gradient $(10-38 \%)$. Twelve fractions were collected and equivalent volumes from each fraction were analyzed by Western blots for the proteins indicated on the left. Two distinct vesicle pools were discernable by size and protein content, the SVP corresponding to fractions 3 and 4 was defined by its high enrichment in bona fide synaptic vesicle component VAMP (left box). The LVP comprising fractions 7-10 was defined by enrichment of larger Rab-5-containing endosomal organelles (right box). C, EMs of vesicle populations present in pooled SVP fractions 3 and 4 (left), and pooled LVP fractions 7-9 (right). Insets are magnified images from representative EM pictures from each vesicle pool. Arrowheads point to $\sim 50 \mathrm{~nm}$ vesicles present in SVP fraction, and arrow points to an example of larger organelles present in LVP fraction. Scale bar, $100 \mathrm{~nm}$.

"leakage," significant amounts of motor protein subunits are present in both the SVP and the LVP fractions (Fig. 6B). On the other hand, BACE1 and PSEN1 cofractionated with APP mainly in LVP fractions (Fig. 6B). Together these results suggest that synaptosomal APP-containing vesicles differ in size and protein content, with the bulk of APP associated with larger synaptosomal organelles that might also contain motor proteins, BACE1 and PSEN1.

\section{Kinesin- 1 associated APP-vesicles contain $\beta$-secretase, PSEN1, and proteins linked to neuronal functions}

To test for the existence of APP-vesicles containing motor proteins, BACE and PSEN1 we immunoisolated APPcontaining vesicles from LVP sucrose gradient fractions using magnetic beads conjugated with anti-APP antibodies. Magnetic beads conjugated with irrelevant anti-GFP antibodies were used as a negative control. EMs of these negative control beads revealed a surface free of organelles or vesicles (Fig. 7A, CTL). The surface of APP-coated beads was decorated with pleomorphic organelles ranging from $\sim 80$ to $250 \mathrm{~nm}$ including unilamellar clear-centered structures, as well as bilamellar and multivesicular bodies (Fig. 7A, arrowheads). For comparison, and to assess specificity of our assay, we used anti-APP- coated beads to immunoisolate APP vesicles from SVP sucrose gradient fractions. Unlike LVP fractions, the surface of APPcoated beads used to immunoisolate APP-containing vesicles from the SVP fraction was covered with a homogenous population of small vesicles ( $<50 \mathrm{~nm}$ diameter; Fig. $7 B$, top), which are morphologically similar to bona fide synaptic vesicles from the same fraction immunoisolated with anti-synaptotagmincoated magnetic beads (Fig. $7 B$, bottom left) as previously reported (Abe et al., 2009). The presence of APP in bona fide synaptic vesicles might represent a synaptic vesicle recycling pool containing endocytosed APP that is subsequently sorted away from neurotransmitter-containing synaptic vesicles (Ikin et al., 1996; Marquez-Sterling et al., 1997). However, a recent study points to the existence of a bona fide APPcontaining synaptic vesicle population that undergoes endocytosis/exocytosis cycles in response to neuronal activity (Groemer et al., 2011). Our findings support the association of APP with a population of synaptic-like vesicles, but cannot unambiguously distinguish between these two possibilities. Nevertheless, it demonstrates that using magnetic beads coated with anti-APP antibodies specifically immunoisolates distinct APP-containing vesicle populations from fractionated mouse synaptosomes. 
A

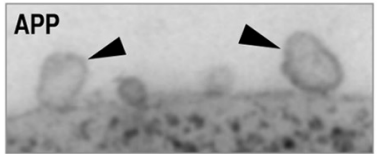
APP

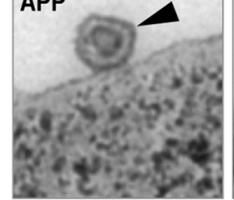
APP

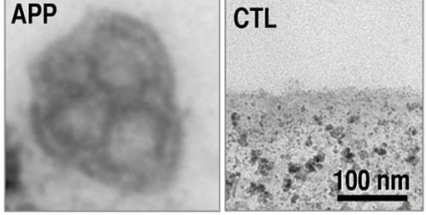

LVP

C
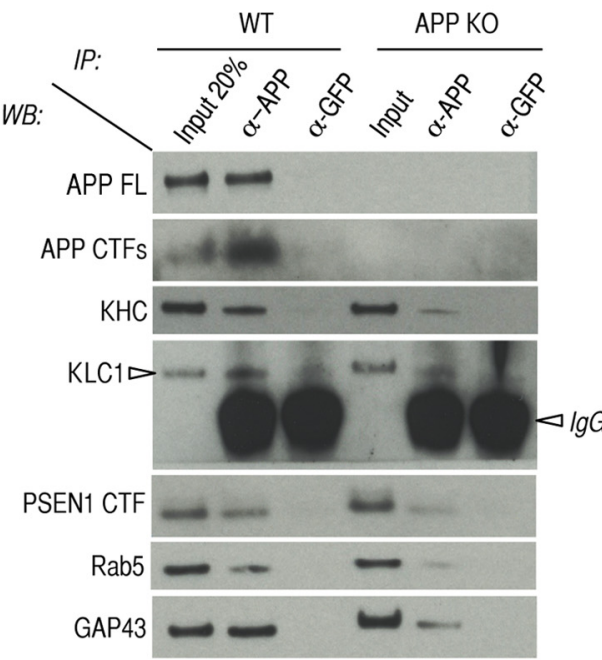

B

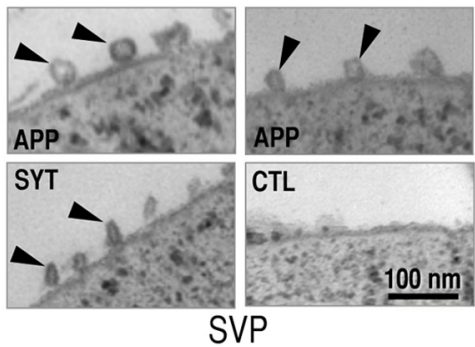

D

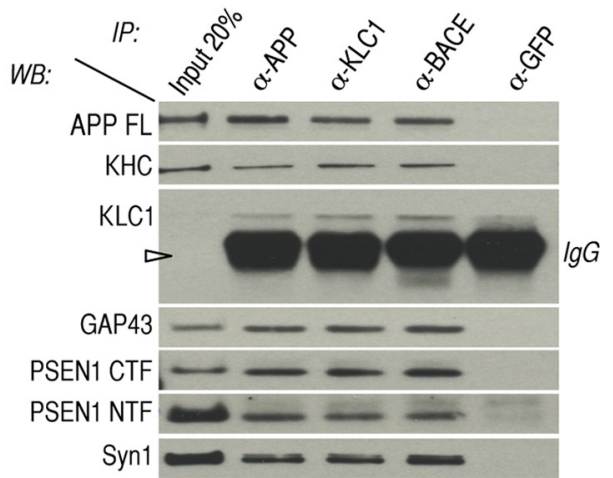

\section{$\mathbf{E}$ \\ Mass Spec Analysis \\ Vesicle Composition \\ (predicted proteins)}

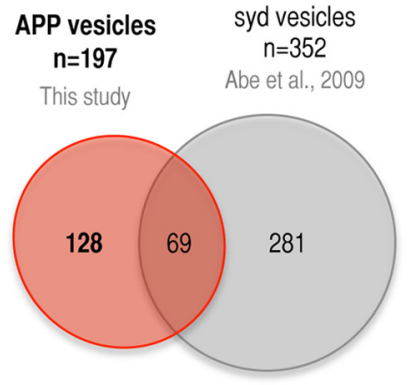

Figure 7. APP immunoisolates contain morphologically heterogenous organelles containing motor proteins and the secretase machinery. $\boldsymbol{A}$, EM of LVP fraction incubated with magnetic beads coated with APP antibodies and GFP as negative control. Representative EMs show no material on GFP-coated magnetic bead surface. Representative EMs show a heterogeneous population of vesicles (arrowheads) decorating the surface of APP beads. B, Electron micrograph of SVP fraction incubated with magnetic beads coated with APP, synaptotagmin (SYT), or GFP antibodies. Representative EMs show no material on GFP-coated magnetic bead surface. Representative EMs show a homogenous population of $\sim 50 \mathrm{~nm}$ vesicles (arrowheads) decorating the surface of APPand SYT-coated beads. C, APP immunoisolates from LVP from either wild-type or APP KO synaptosomes were analyzed by Western blots with indicated antibodies. D, Immunoisolates from LVP fractionated from wild-type mice using APP, BACE1, KLC1, and GFP antibodies were analyzed by Western blot and probed for indicated antibodies on the left. $\boldsymbol{E}$, Venn diagram of predicted proteins obtained from APP and syd immunoisolates (Abe et al., 2009) obtained from mouse synaptosomal LVP fractions.

To assess whether motor proteins and $\gamma$-secretase components are specifically associated with large synaptosomal APP vesicles we analyzed APP immunoisolates from LVP fractions from wild-type and APP-null mice by Western blots. APPvesicle immunoisolates from wild-type mice contained APP FL and APP CTFs (Fig. 7C), which were not detected in immunoisolates from APP KO mice or when using irrelevant $\alpha$-GFP antibodies (Fig. 7C). APP immunoisolates contained the early endosomal marker Rab5 as previously described
(Ikin et al., 1996; Steuble et al., 2012). Kinesin-1 components and PSEN1 were also found in APP immunoisolates from wild-type mice (Fig. 7C,D). Supporting the hypothesis of "APP specificity," APP immunoisolates using LVP obtained from APP-null mice showed barely detectable amounts of these components (Fig. 7C). Furthermore, reverse immunoisolation from LVP of wild-type mice with antibodies to KLC1, and BACE1 confirmed the co-immunoisolation of APP and PSEN1 (Fig. 7D). Therefore, this population of synapto- 
Table 1. List of proteins co-immunoisolated with APP vesicles listing the gene name, Accession number, number of unique peptides, and \% sequence coverage

\begin{tabular}{|c|c|c|c|c|}
\hline Gene & $\begin{array}{l}\text { Accession } \\
\text { number }\end{array}$ & Entry_name & $\begin{array}{l}\text { Unique peptide } \\
\text { number }\end{array}$ & $\begin{array}{l}\text { Sequence } \\
\text { coverage } \\
(\%)\end{array}$ \\
\hline 1110030H18Rik & IPI00402779 & $61 \mathrm{kDa}$ protein & 3 & 7 \\
\hline 2310067E08Rik & IPI00470004 & Probable endonuclease KIAA0830 precursor & 2 & 9 \\
\hline 4932438A13Rik & IPI00670674 & $\begin{array}{l}0 \text { d neonate kidney cDNA, RIKEN full-length enriched library, clone:D630029K19 product:hypothetical } \\
\text { serine-rich region containing protein, full insert sequence }\end{array}$ & 2 & 4 \\
\hline Acsl3 & IPI00651798 & Acyl-CoA synthetase long chain family member 3 & 4 & 8 \\
\hline Actr2 & IPI00457901 & $\begin{array}{l}12 \text { d embryo female Mullerian duct includes surrounding region cDNA, RIKEN full-length enriched } \\
\text { library, clone:6820402C04 product:ACTIN-LIKE PROTEIN } 2\end{array}$ & 3 & 10 \\
\hline Amph & IPI00400180 & Amphiphysin & 12 & 23 \\
\hline Ap2m1 & IPI00622811 & $\begin{array}{l}\text { Osteoclast-like cell cDNA, RIKEN full-length enriched library, clone:I420023G04 product:adaptor } \\
\text { protein complex AP-2, mu1, full insert sequence }\end{array}$ & 25 & 59 \\
\hline Aplp2 & IPI00133421 & Aplp2 protein & 2 & 4 \\
\hline Arl8a & IPI00124610 & Arl10b protein & 4 & 25 \\
\hline Arl8b & IPI00133218 & $\begin{array}{l}\text { Bone marrow macrophage CDNA, RIKEN full-length enriched library, clone:I830086G02 product:ADP- } \\
\text { ribosylation factor-like 10C, full insert sequence }\end{array}$ & 3 & 22 \\
\hline Atp2a1 & IPI00311654 & Sarcoplasmic/endoplasmic reticulum calcium ATPase 1 & 8 & 11 \\
\hline Atp2a2 & IPI00468900 & Splice Isoform SERCA2A of Sarcoplasmic/endoplasmic reticulum calcium ATPase 2 & 25 & 32 \\
\hline Atp2b4 & IPI00378453 & & 35 & 34 \\
\hline Atp6v0a1 & IPI00138232 & Atp6v0a1 protein & 28 & 39 \\
\hline Atp6v0d1 & IPI00313841 & Vacuolar ATP synthase subunit d & 16 & 45 \\
\hline Atp6v1c1 & IPI00314872 & $\begin{array}{l}17 \text { d pregnant adult female amnion cDNA, RIKEN full-length enriched library, clone:1920065A01 } \\
\text { product:ATPase, H + transporting, V1 subunit C, isoform 1, full insert sequence }\end{array}$ & 7 & 19 \\
\hline Atp6v1e1 & IPI00409922 & $\begin{array}{l}\text { CRL-1722 L5178Y-R cDNA, RIKEN full-length enriched library, clone:1730025H19 product:ATPase, } \\
\qquad \mathrm{H}+\text { transporting, V1 subunit E isoform 1, full insert sequence }\end{array}$ & 14 & 58 \\
\hline Atp6v1g2 & IPI00123817 & Vacuolar ATP synthase subunit G 2 & 6 & 62 \\
\hline Atp8a1 & IPI00112776 & Probable phospholipid-transporting ATPase IA & 21 & 22 \\
\hline B230206N24Rik & IPI00461626 & Hypothetical protein B230206N24Rik & 7 & 13 \\
\hline $\mathrm{BC} 026657$ & IPI00553590 & $\begin{array}{l}12 \text { d embryo eyeball cDNA, RIKEN full-length enriched library, clone:D230036B16 product:similar to } \\
\text { KIAA1217 PR0TEIN }\end{array}$ & 2 & 8 \\
\hline Bcas1 & IPI00330860 & Bcas1 protein & 4 & 10 \\
\hline Bcas3 & IPI00648246 & Breast carcinoma amplified sequence 3 & 2 & 6 \\
\hline Calm2 & IPI00467841 & & 11 & 57 \\
\hline Calml3 & IPI00109368 & Calmodulin-like 3 & 4 & 15 \\
\hline Canx & IPI00119618 & Calnexin precursor & 13 & 21 \\
\hline Cct4 & IPI00116277 & T-complex protein 1, delta subunit & 2 & 5 \\
\hline $\mathrm{Clcn} 3$ & IPI00126619 & Chloride channel protein 3 & 3 & 3 \\
\hline Clu & IPI00320420 & Clusterin precursor & 4 & 14 \\
\hline Corola & IPI00323600 & Coronin-1A & 6 & 21 \\
\hline Cplx2 & IPI00111501 & Complexin-2 & 4 & 38 \\
\hline Cpne4 & IPI00407137 & $\begin{array}{l}\text { Adult male brain cDNA, RIKEN full-length enriched library, clone:3632411M23 product:weakly similar } \\
\text { to COPINE VII }\end{array}$ & 6 & 17 \\
\hline Dnaja1 & IPI00132208 & DnaJ homolog subfamily A member 1 & 4 & 12 \\
\hline Dpp6 & IPI00130389 & $\begin{array}{l}\text { Visual cortex cDNA, RIKEN full-length enriched library, clone:K530020M04 product:dipeptidyl pepti- } \\
\text { dase 6, full insert sequence }\end{array}$ & 13 & 23 \\
\hline Dync1li1 & IPI00153421 & Dynein light intermediate chain 1, cytosolic & 2 & 8 \\
\hline Eef2 & IPI00466069 & Elongation factor 2 & 4 & 6 \\
\hline Eif4b & IPI00221581 & Eukaryotic translation initiation factor $4 \mathrm{~B}$ & 3 & 7 \\
\hline Eno2 & IPI00122684 & Eno2 protein & 16 & 56 \\
\hline Ephb3 & IPI00387374 & Eph receptor B3 & 4 & 5 \\
\hline Epn1 & IPI00330477 & Splice Isoform 2 of Epsin-1 & 4 & 17 \\
\hline Eps15l1 & IPI00420187 & Splice Isoform 3 of Epidermal growth factor receptor substrate 15-like 1 & 2 & 4 \\
\hline Fkbp1a & IPI00266899 & FK506-binding protein $1 \mathrm{~A}$ & 2 & 27 \\
\hline Fscn1 & IPI00353563 & Fascin & 5 & 13 \\
\hline Gabra1 & IPI00113772 & Gamma-aminobutyric-acid receptor alpha-1 subunit precursor & 7 & 13 \\
\hline Gap43 & IPI00128973 & Neuromodulin & 23 & 85 \\
\hline Gda & IPI00458508 & $\begin{array}{l}10 \text { d neonate cortex cDNA, RIKEN full-length enriched library, clone:A830088F01 product:guanine } \\
\text { deaminase, full insert sequence }\end{array}$ & 3 & 16 \\
\hline Gm1052 & IPI00378764 & PREDICTED: similar to Neurosecretory protein VGF precursor (VGF8a protein) isoform 1 & 6 & 17 \\
\hline Gnaz & IPI00230193 & Guanine nucleotide-binding protein G(z), alpha subunit & 13 & 41 \\
\hline Gnb1 & IPI00120716 & & 19 & 83 \\
\hline Got1 & IPI00230204 & Aspartate aminotransferase, cytoplasmic & 4 & $\begin{array}{l}15 \\
\text { el contin }\end{array}$ \\
\hline
\end{tabular}


Table 1. Continued

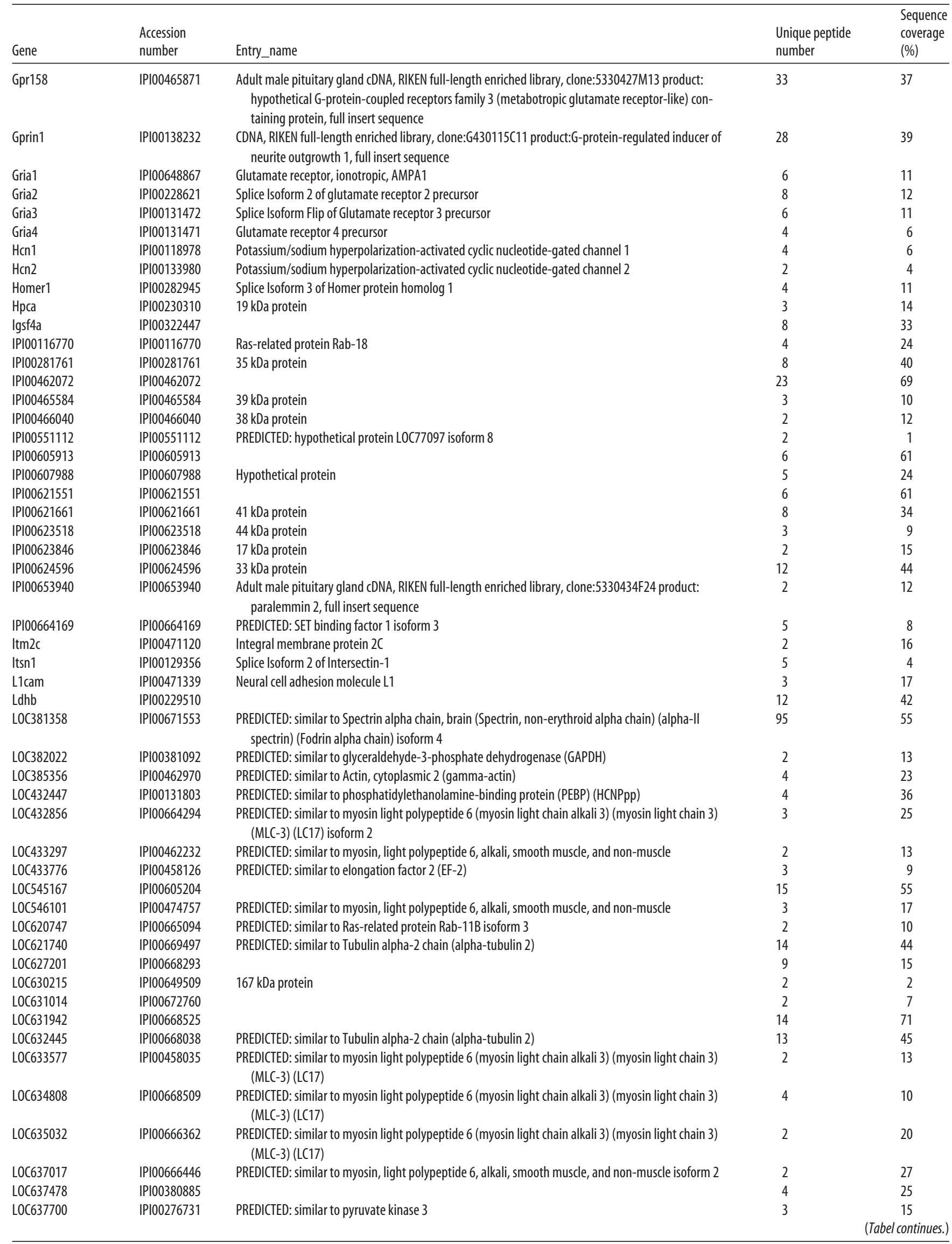


Table 1. Continued

\begin{tabular}{|c|c|c|c|c|}
\hline Gene & $\begin{array}{l}\text { Accession } \\
\text { number }\end{array}$ & Entry_name & $\begin{array}{l}\text { Unique peptide } \\
\text { number }\end{array}$ & $\begin{array}{l}\text { Sequence } \\
\text { coverage } \\
(\%)\end{array}$ \\
\hline LOC638031 & IPI00670985 & $\begin{array}{l}\text { PREDICTED: similar to peptidyl-prolyl cis-trans isomerase A (PPlase) (Rotamase) (Cyclophilin A) } \\
\text { (Cyclosporin A-binding protein) (SP18) }\end{array}$ & 6 & 23 \\
\hline LOC639192 & IPI00667345 & PREDICTED: similar to elongation factor 2 (EF-2) & 3 & 8 \\
\hline LOC640703 & IPI00265576 & PREDICTED: similar to calmodulin 1 isoform 1 & 5 & 34 \\
\hline Lrp1 & IPI00119063 & AM2 receptor & 28 & 9 \\
\hline Mbp & IPI00223375 & Splice Isoform 2 of myelin basic protein & 6 & 28 \\
\hline Mtap1b & IPI00130920 & Microtubule-associated protein 1B & 19 & 12 \\
\hline Myl6 & IPI00653448 & $\begin{array}{l}\text { TIB-55 BB88 cDNA, RIKEN full-length enriched library, clone:I730033H03 product:myosin, light poly- } \\
\text { peptide 6, alkali, smooth muscle, and non-muscle, full insert sequence }\end{array}$ & 2 & 22 \\
\hline Nap114 & IPI00625853 & $\begin{array}{l}\text { Bone marrow stroma cell CRL-2028 SR-4987 CDNA, RIKEN full-length enriched library, clone: } \\
\text { G430136P17 product:nucleosome assembly protein 1-like 4, full insert sequence }\end{array}$ & 3 & 9 \\
\hline Napa & IPI00118930 & Alpha-soluble NSF attachment protein & 8 & 43 \\
\hline Napb & IPI00311515 & Beta-soluble NSF attachment protein & 18 & 74 \\
\hline Napg & IPI00665796 & PREDICTED: N-ethylmaleimide sensitive fusion protein attachment protein gamma isoform 5 & 2 & 26 \\
\hline Ndrg3 & IPI00136107 & NDRG3 protein & 5 & 23 \\
\hline Ndrl & IPI00268244 & $42 \mathrm{kDa}$ protein & 3 & 19 \\
\hline Ne01 & IPI00222057 & $\begin{array}{l}13 \text { d embryo lung CDNA, RIKEN full-length enriched library, clone:D430023D05 product:neogenin, full } \\
\text { insert sequence }\end{array}$ & 4 & 4 \\
\hline Nlgn2 & IPI00468605 & Neuroligin-2 precursor & 4 & 8 \\
\hline Nrxn1 & IPI00656197 & Splice Isoform 4 of neurexin-1-alpha precursor & 4 & 11 \\
\hline Nsfl1c & IPI00399449 & Splice Isoform 1 of NSFL1 cofactor p47 & 2 & 10 \\
\hline Numb & IPI00221545 & Splice Isoform 4 of Protein numb homolog & 3 & 6 \\
\hline Numbl & IPI00608106 & Numbl protein & 6 & 12 \\
\hline Opcml & IPI00463489 & $\begin{array}{l}\text { Visual cortex CDNA, RIKEN full-length enriched library, clone:K230009E18 product:opioid binding } \\
\text { protein/cell adhesion molecule (OBCAM) (opioid-binding cell adhesion molecule) (OPCML) } \\
\text { homolog }\end{array}$ & 14 & 40 \\
\hline Pag1 & IPI00307892 & Phosphoprotein associated with glycosphingolipid-enriched microdomains 1 & 2 & 7 \\
\hline Pak1 & IPI00132993 & Serine/threonine-protein kinase PAK 1 & 3 & 8 \\
\hline Pcdh10 & IPI00165857 & OL-protocadherin isoform & 2 & 2 \\
\hline Pcdh7 & IPI00128022 & $\begin{array}{l}\text { Adult male spinal cord cDNA, RIKEN full-length enriched library, clone:A330101020 product:proto- } \\
\text { cadherin 7, full insert sequence. }\end{array}$ & 4 & 6 \\
\hline Pde10a & IPI00468960 & Pde10a & 7 & 14 \\
\hline Pde2a & IPI00652772 & $\begin{array}{l}\text { Visual cortex CDNA, RIKEN full-length enriched library, clone:K430359B14 product:phosphodiesterase } \\
\text { 2A, cGMP-stimulated, full insert sequence }\end{array}$ & 4 & 13 \\
\hline Pdia3 & IPI00230108 & $\begin{array}{l}\text { CRL-1722 L5178Y-R cDNA, RIKEN full-length enriched library, clone:1730028105 product:glucose } \\
\text { regulated protein, full insert sequence }\end{array}$ & 19 & 38 \\
\hline Pex2 & IPI00416130 & Splice Isoform 4 of PEX5-related protein & 2 & 6 \\
\hline Pgam2 & IPI00230706 & Phosphoglycerate mutase 2 & 4 & 10 \\
\hline Pitpnm2 & IPI00462406 & Pitpnm2 protein & 2 & 2 \\
\hline Plp1 & IPI00230610 & Splice Isoform DM-20 of Myelin proteolipid protein & 4 & 15 \\
\hline Plxna2 & IPI00137313 & Plexin 2 & 7 & 5 \\
\hline Plxnd1 & IPI00471022 & CDNA, RIKEN full-length enriched library, clone:M5C1058N16 product:plexin D1, full insert sequence & 5 & 4 \\
\hline Ppia & IPI00551246 & $17 \mathrm{kDa}$ protein & 9 & 64 \\
\hline Рpp3ca & IPI00459334 & $\begin{array}{l}\text { Adult male testis cDNA, RIKEN full-length enriched library, clone:4921515K14 product:protein phos- } \\
\text { phatase 3, catalytic subunit, alpha isoform, full insert sequence. }\end{array}$ & 5 & 27 \\
\hline Prdx5 & IPI00474055 & Peroxiredoxin 5 , mitochondrial precursor & 2 & 19 \\
\hline Prkcc & IPI00122069 & Protein kinase C, gamma type & 22 & 39 \\
\hline Prnp & IPI00120793 & Major prion protein precursor & 3 & 8 \\
\hline Psen1 & IPI00117124 & Splice Isoform 1 of presenilin-1 & 2 & 8 \\
\hline Ptprn2 & IPI00118191 & Splice Isoform 1 of receptor-type tyrosine-protein phosphatase N2 precursor & 5 & 7 \\
\hline Ptprs & IPI00621605 & $\begin{array}{l}\text { Osteoclast-like cell cDNA, RIKEN full-length enriched library, clone:I420015N06 product:protein } \\
\text { tyrosine phosphatase, receptor type, S, full insert sequence }\end{array}$ & 19 & 21 \\
\hline Qdpr & IPI00459279 & Dihydropteridine reductase & 4 & 30 \\
\hline Rab10 & IPI00130118 & Ras-related protein Rab-10 & 6 & 27 \\
\hline Rab3a & IPI00122965 & Ras-related protein Rab-3A & 16 & 65 \\
\hline Rab3d & IPI00116688 & Ras-related protein Rab-3D & 9 & 37 \\
\hline Rab4b & IPI00654255 & Ras-related protein Rab-4B & 2 & 11 \\
\hline Rob02 & IPI00420291 & Splice Isoform 1 of Roundabout homolog 2 precursor & 2 & 3 \\
\hline Rtn3 & IPI00474993 & $\begin{array}{l}\text { Adult male medulla oblongata cDNA, RIKEN full-length enriched library, clone:6330592M02 product: } \\
\text { reticulon 3, full insert sequence }\end{array}$ & 9 & 24 \\
\hline Rtn4 & IPI00270767 & RTN4 & 11 & $\begin{array}{c}14 \\
\text { (Tabel continues.) }\end{array}$ \\
\hline
\end{tabular}


Table 1. Continued

\begin{tabular}{|c|c|c|c|c|}
\hline Gene & $\begin{array}{l}\text { Accession } \\
\text { number }\end{array}$ & Entry_name & $\begin{array}{l}\text { Unique peptide } \\
\text { number }\end{array}$ & $\begin{array}{l}\text { Sequence } \\
\text { coverage } \\
(\%)\end{array}$ \\
\hline Scamp3 & IPI00653426 & $\begin{array}{l}\text { N0D-derived CD11c + ve dendritic cells cDNA, RIKEN full-length enriched library, clone:F630019A21 } \\
\text { product:secretory carrier membrane protein 3, full insert sequence }\end{array}$ & 2 & 10 \\
\hline Scn1a & IPI00673613 & PREDICTED: sodium channel, voltage-gated, type I, alpha isoform 3 & 9 & 6 \\
\hline Sdfr1 & IPI00459329 & Splice Isoform 4 of stromal cell-derived receptor 1 precursor & 3 & 19 \\
\hline $\operatorname{Sec} 2211$ & IPI00114368 & Vesicle trafficking protein SEC22b & 5 & 28 \\
\hline Sez612 & IPI00460662 & Sez612 protein & 5 & 10 \\
\hline Sh3gl2 & IPI00649333 & 20 kDa protein & 5 & 33 \\
\hline Slc30a3 & IPI00125397 & Zinc transporter 3 & 7 & 29 \\
\hline Slc6a17 & IPI00626017 & $81 \mathrm{kDa}$ protein & 11 & 18 \\
\hline Slc7a14 & IPI00226807 & & 5 & 8 \\
\hline Slc8a2 & IPI00170310 & Sodium-calcium exchanger & 20 & 29 \\
\hline Slc9a1 & IPI00380785 & Slc9a1 protein & 5 & 10 \\
\hline Slc9a6 & IPI00225023 & $\begin{array}{l}\text { Adult male olfactory brain cDNA, RIKEN full-length enriched library, clone:6430520C02 product: } \\
\text { SODIUM/HYDROGEN EXCHANGER 6 (NA(+)/H(+) EXCHANGER 6) homolog }\end{array}$ & 3 & 6 \\
\hline Snap91 & IPI00474209 & $\begin{array}{l}\text { Osteoclast-like cell cDNA, RIKEN full-length enriched library, clone:I420024G24 product:synaptosom- } \\
\text { al-associated protein 91, full insert sequence }\end{array}$ & 5 & 20 \\
\hline Srgap3 & IPI00415257 & Splice Isoform 3 of SLIT-ROBO Rho GTPase-activating protein 3 & 3 & 4 \\
\hline Stmn1 & IPI00648723 & 12 kDa protein & 8 & 68 \\
\hline Stx7 & IPI00118217 & Syntaxin-7 & 6 & 30 \\
\hline Stxbp1 & IPI00415402 & & 37 & 61 \\
\hline Stxbp5 & IPI00661695 & & 3 & 22 \\
\hline Sv2b & IPI00626096 & 77 kDa protein & 7 & 13 \\
\hline Syngr3 & IPI00331579 & Synaptogyrin-3 & 3 & 15 \\
\hline Synpr & IPI00378621 & Splice Isoform 1 of Synaptoporin & 2 & 6 \\
\hline Syp & IPI00123505 & Synaptophysin & 5 & 13 \\
\hline Syt1 & IPI00129618 & Synaptotagmin-1 & 28 & 53 \\
\hline Syt12 & IPI00120798 & Synaptotagmin-12 & 4 & 12 \\
\hline Syt2 & IPI00129622 & Synaptotagmin-2 & 12 & 28 \\
\hline Tbc1d10b & IPI00469012 & 1110003P22Rik protein & 2 & 5 \\
\hline Thy1 & IPI00109727 & Thy-1 membrane glycoprotein precursor & 7 & 38 \\
\hline Tmed10 & IPI00466570 & Splice Isoform 1 of transmembrane emp24 domain containing protein 10 precursor & 3 & 18 \\
\hline Tmem24 & IPI00461711 & & 3 & 13 \\
\hline Tmem30a & IPI00387318 & $\begin{array}{l}\text { Bone marrow macrophage cDNA, RIKEN full-length enriched library, clone:G530126G10 product: } \\
\text { hypothetical eukaryotic protein of unknown function DUF284 containing protein, full insert } \\
\text { sequence }\end{array}$ & 5 & 17 \\
\hline Tnik & IPI00666749 & PREDICTED: Traf2 and NCK interacting kinase-like isoform 12 & 2 & 1 \\
\hline Tnr & IPI00553593 & Splice Isoform 2 of Tenascin-R precursor & 5 & 6 \\
\hline Tuba1 & IPI00604879 & & 17 & 41 \\
\hline Tuba2 & IPI00117348 & & 17 & 45 \\
\hline Tuba6 & IPI00403810 & & 17 & 40 \\
\hline Tyro3 & IPI00404701 & 93 kDa protein & 2 & 4 \\
\hline Usp5 & IPI00113214 & Ubiquitin carboxyl-terminal hydrolase 5 & 9 & 19 \\
\hline Vamp1 & IPI00621652 & Vamp1 protein & 5 & 44 \\
\hline Vamp2 & IPI00229703 & & 6 & 46 \\
\hline Vсрір1 & IPI00466186 & Splice Isoform 1 of Deubiquitinating protein VCIP135 & 3 & 5 \\
\hline Vti1a & IPI00131540 & Vti1a protein & 6 & 20 \\
\hline Wasf1 & IPI00471372 & Wiskott-Aldrich syndrome protein family member 1 & 7 & 17 \\
\hline Wnk2 & IPI00652201 & $\begin{array}{l}\text { Adult retina cDNA, RIKEN full-length enriched library, clone:A930010D21 product:similar to protein } \\
\text { kinase, lysine deficient } 1 \text { homolog }\end{array}$ & 3 & 3 \\
\hline Ywhag & IPI00405385 & $5 \mathrm{kDa}$ protein & 2 & 35 \\
\hline Ywhaq & IPI00656269 & Splice Isoform 2 of $14-3-3$ protein theta & 11 & 39 \\
\hline Ywhaz & IPI00473203 & $\begin{array}{l}\text { Adult pancreas islet cells cDNA, RIKEN full-length enriched library, clone:C820005J08 product:tyrosine } \\
\text { 3-monooxygenase/tryptophan 5- monooxygenase activation protein, zeta polypeptide, full insert } \\
\text { sequence }\end{array}$ & 9 & 46 \\
\hline
\end{tabular}

somal vesicles containing APP, kinesin-1, BACE, and PSEN1, suggests the existence of an axonally transported APP vesicle containing the amyloidogenic secretase machinery.

In APP, kinesin, BACE1, and PSEN1 immunoisolates we also found growth-associated protein 43 (GAP43) and synapsin-1 (syn 1 ), two previously proposed components of axonally transported APP vesicles (Kamal et al., 2001; Fig.
$7 C, D)$, suggesting that APP vesicles might carry components required for proper neuronal functions. Since failure to correctly deliver axonal APP-containing vesicles may have important functional consequences that might ultimately lead to disease, we determined the composition of APP-containing vesicles by MS analysis. For this analysis, proteins were scored positive when present with at least a twofold increase in spec- 
tra count relative to their respective negative control (Abe et al., 2009) and when detected in at least two separate experimental immunoisolations. In total, $\sim 197$ proteins fulfilled these criteria (Table 1). Some proteins described previously to interact with APP or APP vesicles such as GAP43, Rab3a, X11, Numb, LRP, PrionP, and APLP2 are included in this list (Table $1)$. To test the specificity of APP immunoisolates we crosscompared our lists of proteins with those of Sunday driver (syd)-containing vesicles isolated similarly from synaptosomal LVP fractions obtained in parallel experiments (Abe et al., 2009). Approximately $2 / 3$ of the proteins detected in APP immunoisolates were not detected in syd vesicles (Fig. 7E; Abe et al., 2009).

\section{Discussion}

Our data lead to three principal conclusions. First, UV irradiation substantially accelerates secretase cleavage of endogenous APP and related APLP1 and APLP2 in neuronal cells leading to rapid decay of FL and membrane-associated CTF forms of APP, APLP1, and APLP2. This accelerated secretase cleavage of APP depends in part upon endocytic and lysosomal pathways. Second, enhanced APP cleavage impairs APP axonal transport. Third, some APP vesicles in synaptosomes contain $\beta$ - and $\gamma$-secretases, kinesin-1, and other proteins that might modulate APP processing, APP axonal transport, and other key neuronal functions.

\section{DNA damage-inducing agents accelerate APP, APLP1, and APLP2 processing}

While all APP family members can be sequentially cleaved by similar secretase activities, the extracellular and/or intracellular stimuli modulating secretase activities are not well understood. Here, we found that damage in the form of UV irradiation substantially accelerates the processing rate of APP family members, but not other well known $\gamma$-secretase substrates. This effect is particularly crucial for proteins with a short half-life such as APP and its family members since UV irradiation induces rapid decline of FL and CTF fragments.

Our findings are consistent to some extent with studies showing that DNA damage-inducing agents camptothecin and etoposide elicit APP $\gamma$-secretase processing (Jin et al., 2007, 2008; Minopoli et al., 2007), and with reports showing that exposure of different cell types to UV or camptothecin leads to reduced APP FL levels (Cuesta et al., 2009a,b). In contrast to previous findings attributing loss of APP to reduced transcription (Cuesta et al., $2009 \mathrm{~b}$ ), we found that UV irradiation leads to increased APP, $A P L P 1$, and APLP2 mRNA suggesting that UV-induced APP decline is independent of transcription. In agreement with our findings, many previous studies suggest that injury and ischemic insults induce APP expression and APP processing as a part of cellular stress responses (Roberts et al., 1991; Scott et al., 1991; Van den Heuvel et al., 1999; Shi et al., 2000; Smith et al., 2003; Chen et al., 2004; Lee et al., 2006; Li et al., 2009). Supporting this view, mice or flies lacking APP or APLP, respectively, are more sensitive to brain injury (Leyssen et al., 2005; Corrigan et al., 2012).

The current consensus is that $\alpha$-cleavage of APP occurs mainly at the plasma membrane while $\beta$ - and $\gamma$-cleavage occur mostly in endocytic/lysosomal compartments (Koo and Squazzo, 1994; Carey et al., 2005; Cirrito et al., 2008). We observed that inhibition of endosomal/lysosomal pathways partially alleviates APP FL and APP CTF reduction induced by UV. Since $\gamma$-secretase but not endosomal/lysosomal pathway inhibition before UV exposure results in APP CTF accumulation, a significant amount of UV-induced $\gamma$-secretase activity must occur in other cellular compartments in addition to endosomes and lysosomes. Our experiments suggest that UV irradiation may initiate an APP cleavage-dependent signaling cascade at the plasma membrane that partially involves an endosomal/lysosomal pathway. This suggestion is consistent with previous reports that UV irradiation induces internalization of epidermal growth factor receptor (EGFR) to early endosomal compartments (Rosette and Karin, 1996; Oksvold et al., 2002). UV irradiation was also suggested to accelerate endocytosis via p38 (Cavalli et al., 2001). Furthermore, different types of radiation have been shown to induce pinocytic and phagocytic activity, as well as structural and functional effects on several intracellular organelles including lysosomes (Somosy, 2000).

\section{UV-induced $\boldsymbol{\gamma}$-secretase activity alters APP axonal transport}

Axonal transport of APP occurs in anterograde and retrograde directions in cultured neurons and in vivo Drosophila larval segmental nerves (Kaether et al., 2000; Falzone et al., 2009; Reis et al., 2012). Anterograde transport of APP might be mediated by direct or indirect interaction of the APP C terminus and KLC1 (Kamal et al., 2000; Inomata et al., 2003; Matsuda et al., 2003). On the other hand, KLC1 and DHC colocalize on APP vesicles in neurons (Szpankowski et al., 2012), and recent reports propose an intimate coordination between kinesin and dynein-dependent movement of APP vesicles (Reis et al., 2012) that might involve interactions of JIP-1 with KHC or with the dynactin component P150 ${ }^{\text {glued }}$ (Fu and Holzbaur, 2013). Therefore, it is not surprising that both anterograde and retrograde transport of APP is simultaneously affected after UV irradiation.

Although some have challenged this idea (Tienari et al., 1996; Rusu et al., 2007), several studies suggesting that the APP C terminus is sufficient and required for APP axonal transport led to the proposal that APP acts as a cargo receptor for kinesin-1 (Kamal et al., 2000, 2001; Gunawardena and Goldstein, 2001; Satpute-Krishnan et al., 2006). This model predicts that release of AICD from APP by $\gamma$-secretase activity could induce detachment of APP-containing vesicles from the kinesin-1/microtubule transport machinery. Supporting this view, processing of APP induced after sciatic nerve ligation led to increased detachment of kinesin-1 from membrane fractions (Kamal et al., 2001).

Here, we found that UV irradiation can induce reduction of APP-YFP anterograde and retrograde axonal transport without altering the total number of APP-YFP puncta in the axon. These transport defects are prevented by $\gamma$-secretase inhibition. These results support the hypothesis that APP, either directly or indirectly, serves as a cargo receptor, and its cleavage by $\gamma$-secretase could induce detachment of APP vesicles from the transport machinery. Our results cannot rule out the possibility that another transmembrane protein closely associated with APP, and also sensitive to $\gamma$-secretase cleavage, could function as the kinesin-1 receptor for APP cargoes. One such protein could be the transmembrane protein calsyntenin-1 (aka alcadein), which docks kinesin-1 to vesicular cargoes via a direct interaction with KLC1, and might mediate trans-Golgi network exit of APP to cotransport both proteins along the axon (Konecna et al., 2006; Araki et al., 2007; Ludwig et al., 2009; Steuble et al., 2010, 2012; Vagnoni et al., 2012). Furthermore, after ectodomain shedding by ADAM10 but not BACE1, calsyntenin-1 CTF becomes a $\gamma$-secretase substrate (Vogt et al., 2001; Araki et al., 2003; Hata et al., 2009). Therefore, it is plausible that axonal transport of APP/ calsyntenin/kinesin-1 vesicles might terminate after UV exposure via $\gamma$-secretase cleavage of calsyntenin- 1 and its subsequent de- 
tachment from kinesin motor proteins. Although speculative at this point this alternative should be tested.

Our new findings also support the view that the secretase machinery is associated with at least some APP axonal vesicles. In fact, this model has been independently supported by multiple studies but remains controversial. We suggest that at least some disagreement is caused by different expression levels of transfected proteins, particularly when overexpressed proteins are compared with endogenous (Kamal et al., 2001; Kasa et al., 2001; Papp et al., 2002; Sheng et al., 2003; Lazarov et al., 2005; Goldsbury et al., 2006; Nikolaev et al., 2009; Szodorai et al., 2009; Frykman et al., 2010). In further support of our model, we identified a biochemically isolated population of APP vesicles that contain BACE1 and PSEN1. A prediction of our findings is that inhibition of BACE1 and $\gamma$-secretase might protect axonal transport of APP-containing organelles under conditions of cellular damage.

\section{APP synaptosomal vesicles are enriched in neuronal proteins associated with diseases of the nervous system}

Our study suggests that accelerated cleavage of APP might impede axonal transport of APP-containing vesicles, and that impaired axonal transport might be a necessary response during cellular stress situations to increase APP and/or APP-vesicle residents at the soma. Therefore, identifying the protein content of APP axonally transported vesicles is an initial step to fully understand how APP axonal transport contributes to APP-dependent physiological and pathological functions. We identified a population of APP-containing synaptosomal vesicles composed of $\sim 80-200 \mathrm{~nm}$ unilamellar, bilamellar organelles, and multivesicular bodies reminiscent of previously reported APPcontaining vesicles in the axons and synapses of rat brains (Caporaso et al., 1994; Steuble et al., 2012). They are also morphologically similar to endosomal Rab5 vesicles isolated from rat synaptosomes (Ikin et al., 1996), and some are reminiscent of clear-centered pleomorphic calsyntenin-containing vesicles (Steuble et al., 2010). MS of APP vesicles identified 18 of the 55 proteins $(\sim 33 \%)$ associated with calsyntenin-1 vesicles, suggesting that APP immunoisolates might include a calsentynin/ BACE1/APP vesicle population (Steuble et al., 2010).

MS also predicted other components reported to interact with APP or APP vesicles including PSEN1, GAP43, Rab3a, syntaxin, SV2, and synaptotagmin (Kamal et al., 2001; Szodorai et al., 2009; Kohli et al., 2012). To develop hypotheses about the potential functional effects that could be caused by perturbed APP delivery to synapses or other neuronal sites of action, we used GREAT (McLean et al., 2010) to determine potential links between the predicted APP-vesicle residents and disease. Interestingly, we found a strong association with proteins whose dysfunction leads to mouse phenotypes associated with abnormal synaptic transmission, abnormal learning/memory, or abnormal long-term potentiation. We also found a highly enriched association with genes downregulated in $\mathrm{AD}$, as well as genes upregulated in aged human frontal cortex, as well as association with diseases of the nervous system including cognitive disease, schizophrenia, neurodegenerative disease, epilepsy, and neuropathy. Together, these predictions suggest that APP-containing vesicles may carry proteins whose dysfunction is intimately linked to diseases of the nervous system including $\mathrm{AD}$.

\section{References}

Abe N, Almenar-Queralt A, Lillo C, Shen Z, Lozach J, Briggs SP, Williams DS, Goldstein LS, Cavalli V (2009) Sunday driver interacts with two distinct classes of axonal organelles. J Biol Chem 284:34628-34639. CrossRef Medline
Amaratunga A, Fine RE (1995) Generation of amyloidogenic C-terminal fragments during rapid axonal transport in vivo of beta-amyloid precursor protein in the optic nerve. J Biol Chem 270:17268-17272. CrossRef Medline

Amaratunga A, Leeman SE, Kosik KS, Fine RE (1995) Inhibition of kinesin synthesis in vivo inhibits the rapid transport of representative proteins for three transport vesicle classes into the axon. J Neurochem 64:2374-2376. Medline

Araki Y, Tomita S, Yamaguchi H, Miyagi N, Sumioka A, Kirino Y, Suzuki T (2003) Novel cadherin-related membrane proteins, Alcadeins, enhance the X11-like protein-mediated stabilization of amyloid beta-protein precursor metabolism. J Biol Chem 278:49448-49458. CrossRef Medline

Araki Y, Kawano T, Taru H, Saito Y, Wada S, Miyamoto K, Kobayashi H, Ishikawa HO, Ohsugi Y, Yamamoto T, Matsuno K, Kinjo M, Suzuki T (2007) The novel cargo Alcadein induces vesicle association of kinesin-1 motor components and activates axonal transport. EMBO J 26:14751486. CrossRef Medline

Beher D, Elle C, Underwood J, Davis JB, Ward R, Karran E, Masters CL, Beyreuther K, Multhaup G (1999) Proteolytic fragments of Alzheimer's disease-associated presenilin 1 are present in synaptic organelles and growth cone membranes of rat brain. J Neurochem 72:1564-1573. Medline

Brunholz S, Sisodia S, Lorenzo A, Deyts C, Kins S, Morfini G (2012) Axonal transport of APP and the spatial regulation of APP cleavage and function in neuronal cells. Exp Brain Res 217:353-364. CrossRef Medline

Caporaso GL, Takei K, Gandy SE, Matteoli M, Mundigl O, Greengard P, De Camilli P (1994) Morphologic and biochemical analysis of the intracellular trafficking of the Alzheimer beta/A4 amyloid precursor protein. J Neurosci 14:3122-3138. Medline

Carey RM, Balcz BA, Lopez-Coviella I, Slack BE (2005) Inhibition of dynamin-dependent endocytosis increases shedding of the amyloid precursor protein ectodomain and reduces generation of amyloid beta protein. BMC Cell Biol 6:30. CrossRef Medline

Cavalli V, Vilbois F, Corti M, Marcote MJ, Tamura K, Karin M, Arkinstall S, Gruenberg J (2001) The stress-induced MAP kinase p38 regulates endocytic trafficking via the GDI:Rab5 complex. Mol Cell 7:421-432. CrossRef Medline

Chen XH, Siman R, Iwata A, Meaney DF, Trojanowski JQ, Smith DH (2004) Long-term accumulation of amyloid-beta, beta-secretase, presenilin-1, and caspase- 3 in damaged axons following brain trauma. Am J Pathol 165:357-371. CrossRef Medline

Cirrito JR, Kang JE, Lee J, Stewart FR, Verges DK, Silverio LM, Bu G, Mennerick S, Holtzman DM (2008) Endocytosis is required for synaptic activity-dependent release of amyloid-beta in vivo. Neuron 58:42-51. CrossRef Medline

Cole GM, Huynh TV, Saitoh T (1989) Evidence for lysosomal processing of amyloid beta-protein precursor in cultured cells. Neurochem Res 14:933939. CrossRef Medline

Corrigan F, Vink R, Blumbergs PC, Masters CL, Cappai R, van den Heuvel C (2012) Characterisation of the effect of knockout of the amyloid precursor protein on outcome following mild traumatic brain injury. Brain Res 1451:87-99. CrossRef Medline

Cuesta A, Zambrano A, López E, Pascual A (2009a) Thyroid hormones reverse the UV-induced repression of APP in neuroblastoma cells. FEBS Lett 583:2401-2406. CrossRef Medline

Cuesta A, Zambrano A, Royo M, Pascual A (2009b) The tumour suppressor p53 regulates the expression of amyloid precursor protein (APP). Biochem J 418:643-650. CrossRef Medline

Falzone TL, Stokin GB (2012) Imaging amyloid precursor protein in vivo: an axonal transport assay. Methods Mol Biol 846:295-303. CrossRef Medline

Falzone TL, Stokin GB, Lillo C, Rodrigues EM, Westerman EL, Williams DS, Goldstein LS (2009) Axonal stress kinase activation and tau misbehavior induced by kinesin-1 transport defects. J Neurosci 29:5758-5767. CrossRef Medline

Frykman S, Hur JY, Frånberg J, Aoki M, Winblad B, Nahalkova J, Behbahani H, Tjernberg LO (2010) Synaptic and endosomal localization of active gamma-secretase in rat brain. PLoS One 5:e8948. CrossRef Medline

Fu MM, Holzbaur EL (2013) JIP1 regulates the directionality of APP axonal transport by coordinating kinesin and dynein motors. J Cell Biol 202:495508. CrossRef Medline

Golde TE, Estus S, Younkin LH, Selkoe DJ, Younkin SG (1992) Processing 
of the amyloid protein precursor to potentially amyloidogenic derivatives. Science 255:728-730. CrossRef Medline

Goldsbury C, Mocanu MM, Thies E, Kaether C, Haass C, Keller P, Biernat J, Mandelkow E, Mandelkow EM (2006) Inhibition of APP trafficking by tau protein does not increase the generation of amyloid-beta peptides. Traffic 7:873-888. CrossRef Medline

Goldstein LS (2012) Axonal transport and neurodegenerative disease: can we see the elephant? Prog Neurobiol 99:186-190. CrossRef Medline

Groemer TW, Thiel CS, Holt M, Riedel D, Hua Y, Hüve J, Wilhelm BG, Klingauf J (2011) Amyloid precursor protein is trafficked and secreted via synaptic vesicles. PLoS One 6:e18754. CrossRef Medline

Gunawardena S, Goldstein LS (2001) Disruption of axonal transport and neuronal viability by amyloid precursor protein mutations in Drosophila. Neuron 32:389-401. CrossRef Medline

Haapasalo A, Kovacs DM (2011) The many substrates of presenilin/ $\gamma$ secretase. J Alzheimers Dis 25:3-28. CrossRef Medline

Hata S, Fujishige S, Araki Y, Kato N, Araseki M, Nishimura M, Hartmann D, Saftig P, Fahrenholz F, Taniguchi M, Urakami K, Akatsu H, Martins RN, Yamamoto K, Maeda M, Yamamoto T, Nakaya T, Gandy S, Suzuki T (2009) Alcadein cleavages by amyloid beta-precursor protein (APP) alpha- and gamma-secretases generate small peptides, p3-Alcs, indicating Alzheimer disease-related gamma-secretase dysfunction. J Biol Chem 284:36024-36033. CrossRef Medline

Huttner WB, Schiebler W, Greengard P, De Camilli P (1983) Synapsin I (protein I), a nerve terminal-specific phosphoprotein. III. Its association with synaptic vesicles studied in a highly purified synaptic vesicle preparation. J Cell Biol 96:1374-1388. CrossRef Medline

Ikin AF, Annaert WG, Takei K, De Camilli P, Jahn R, Greengard P, Buxbaum JD (1996) Alzheimer amyloid protein precursor is localized in nerve terminal preparations to Rab5-containing vesicular organelles distinct from those implicated in the synaptic vesicle pathway. J Biol Chem 271: 31783-31786. CrossRef Medline

Inomata H, Nakamura Y, Hayakawa A, Takata H, Suzuki T, Miyazawa K, Kitamura N (2003) A scaffold protein JIP-1b enhances amyloid precursor protein phosphorylation by JNK and its association with kinesin light chain 1. J Biol Chem 278:22946-22955. CrossRef Medline

Ip YT, Davis RJ (1998) Signal transduction by the c-Jun N-terminal kinase (JNK)-from inflammation to development. Curr Opin Cell Biol 10:205219. CrossRef Medline

Israel MA, Yuan SH, Bardy C, Reyna SM, Mu Y, Herrera C, Hefferan MP, Van Gorp S, Nazor KL, Boscolo FS, Carson CT, Laurent LC, Marsala M, Gage FH, Remes AM, Koo EH, Goldstein LS (2012) Probing sporadic and familial Alzheimer's disease using induced pluripotent stem cells. Nature 482:216-220. CrossRef Medline

Jin SM, Cho HJ, Jung MW, Mook-Jung I (2007) DNA damage-inducing agent-elicited gamma-secretase activity is dependent on Bax/Bcl-2 pathway but not on caspase cascades. Cell Death Differ 14:189-192. CrossRef Medline

Jin SM, Cho HJ, Jung ES, Shim MY, Mook-Jung I (2008) DNA damageinducing agents elicit gamma-secretase activation mediated by oxidative stress. Cell Death Differ 15:1375-1384. CrossRef Medline

Kaether C, Skehel P, Dotti CG (2000) Axonal membrane proteins are transported in distinct carriers: a two-color video microscopy study in cultured hippocampal neurons. Mol Biol Cell 11:1213-1224. CrossRef Medline

Kamal A, Stokin GB, Yang Z, Xia CH, Goldstein LS (2000) Axonal transport of amyloid precursor protein is mediated by direct binding to the kinesin light chain subunit of kinesin-I. Neuron 28:449-459. CrossRef Medline

Kamal A, Almenar-Queralt A, LeBlanc JF, Roberts EA, Goldstein LS (2001) Kinesin-mediated axonal transport of a membrane compartment containing beta-secretase and presenilin-1 requires APP. Nature 414:643648. CrossRef Medline

Kang DE, Yoon IS, Repetto E, Busse T, Yermian N, Ie L, Koo EH (2005) Presenilins mediate phosphatidylinositol 3-kinase/AKT and ERK activation via select signaling receptors. Selectivity of PS2 in platelet-derived growth factor signaling. J Biol Chem 280:31537-31547. CrossRef Medline

Kasa P, Papp H, Pakaski M (2001) Presenilin-1 and its N-terminal and C-terminal fragments are transported in the sciatic nerve of rat. Brain Res 909:159-169. CrossRef Medline

Kohli BM, Pflieger D, Mueller LN, Carbonetti G, Aebersold R, Nitsch RM, Konietzko U (2012) Interactome of the amyloid precursor protein APP in brain reveals a protein network involved in synaptic vesicle turnover and a close association with Synaptotagmin-1. J Proteome Res 11:40754090. CrossRef Medline

Konecna A, Frischknecht R, Kinter J, Ludwig A, Steuble M, Meskenaite V, Indermühle $\mathrm{M}$, Engel $\mathrm{M}$, Cen $\mathrm{C}$, Mateos JM, Streit $\mathrm{P}$, Sonderegger $\mathrm{P}$ (2006) Calsyntenin-1 docks vesicular cargo to kinesin-1. Mol Biol Cell 17:3651-3663. CrossRef Medline

Koo EH, Squazzo SL (1994) Evidence that production and release of amyloid beta-protein involves the endocytic pathway. J Biol Chem 269: 17386-17389. Medline

Lazarov O, Morfini GA, Lee EB, Farah MH, Szodorai A, DeBoer SR, Koliatsos VE, Kins S, Lee VM, Wong PC, Price DL, Brady ST, Sisodia SS (2005) Axonal transport, amyloid precursor protein, kinesin-1, and the processing apparatus: revisited. J Neurosci 25:2386-2395. CrossRef Medline

Lee PH, Hwang EM, Hong HS, Boo JH, Mook-Jung I, Huh K (2006) Effect of ischemic neuronal insults on amyloid precursor protein processing. Neurochem Res 31:821-827. CrossRef Medline

Leyssen M, Ayaz D, Hébert SS, Reeve S, De Strooper B, Hassan BA (2005) Amyloid precursor protein promotes post-developmental neurite arborization in the Drosophila brain. EMBO J 24:2944-2955. CrossRef Medline

Li L, Zhang X, Yang D, Luo G, Chen S, Le W (2009) Hypoxia increases Abeta generation by altering beta- and gamma-cleavage of APP. Neurobiol Aging 30:1091-1098. CrossRef Medline

Ludwig A, Blume J, Diep TM, Yuan J, Mateos JM, Leuthäuser K, Steuble M, Streit P, Sonderegger P (2009) Calsyntenins mediate TGN exit of APP in a kinesin-1-dependent manner. Traffic 10:572-589. CrossRef Medline

Lyckman AW, Confaloni AM, Thinakaran G, Sisodia SS, Moya KL (1998) Post-translational processing and turnover kinetics of presynaptically targeted amyloid precursor superfamily proteins in the central nervous system. J Biol Chem 273:11100-11106. CrossRef Medline

Macia E, Ehrlich M, Massol R, Boucrot E, Brunner C, Kirchhausen T (2006) Dynasore, a cell-permeable inhibitor of dynamin. Dev Cell 10:839-850. CrossRef Medline

Marquez-Sterling NR, Lo AC, Sisodia SS, Koo EH (1997) Trafficking of cell-surface beta-amyloid precursor protein: evidence that a sorting intermediate participates in synaptic vesicle recycling. J Neurosci 17:140-151. Medline

Matsuda S, Matsuda Y, D’Adamio L (2003) Amyloid beta protein precursor (AbetaPP), but not AbetaPP-like protein 2, is bridged to the kinesin light chain by the scaffold protein JNK-interacting protein 1. J Biol Chem 278:38601-38606. CrossRef Medline

McLean CY, Bristor D, Hiller M, Clarke SL, Schaar BT, Lowe CB, Wenger AM, Bejerano G (2010) GREAT improves functional interpretation of cis-regulatory regions. Nat Biotechnol 28:495-501. CrossRef Medline

Minopoli G, Stante M, Napolitano F, Telese F, Aloia L, De Felice M, Di Lauro R, Pacelli R, Brunetti A, Zambrano N, Russo T (2007) Essential roles for Fe65, Alzheimer amyloid precursor-binding protein, in the cellular response to DNA damage. J Biol Chem 282:831-835. Medline

Muresan V, Varvel NH, Lamb BT, Muresan Z (2009) The cleavage products of amyloid-beta precursor protein are sorted to distinct carrier vesicles that are independently transported within neurites. J Neurosci 29:35653578. CrossRef Medline

Nikolaev A, McLaughlin T, O'Leary DD, Tessier-Lavigne M (2009) APP binds DR6 to trigger axon pruning and neuron death via distinct caspases. Nature 457:981-989. CrossRef Medline

Nunan J, Shearman MS, Checler F, Cappai R, Evin G, Beyreuther K, Masters CL, Small DH (2001) The C-terminal fragment of the Alzheimer's disease amyloid protein precursor is degraded by a proteasome-dependent mechanism distinct from gamma-secretase. Eur J Biochem 268:53295336. CrossRef Medline

Oksvold MP, Huitfeldt HS, Østvold AC, Skarpen E (2002) UV induces tyrosine kinase-independent internalisation and endosome arrest of the EGF receptor. J Cell Sci 115:793-803. Medline

Papp H, Pakaski M, Kasa P (2002) Presenilin-1 and the amyloid precursor protein are transported bidirectionally in the sciatic nerve of adult rat. Neurochem Int 41:429-435. CrossRef Medline

Reis GF, Yang G, Szpankowski L, Weaver C, Shah SB, Robinson JT, Hays TS, Danuser G, Goldstein LS (2012) Molecular motor function in axonal transport in vivo probed by genetic and computational analysis in Drosophila. Mol Biol Cell 23:1700-1714. CrossRef Medline

Repetto E, Yoon IS, Zheng H, Kang DE (2007) Presenilin 1 regulates epider- 
mal growth factor receptor turnover and signaling in the endosomallysosomal pathway. J Biol Chem 282:31504-31516. CrossRef Medline

Roberts GW, Gentleman SM, Lynch A, Graham DI (1991) beta A4 amyloid protein deposition in brain after head trauma. Lancet 338:1422-1423. CrossRef Medline

Rodrigues EM, Weissmiller AM, Goldstein LS (2012) Enhanced $\beta$-secretase processing alters APP axonal transport and leads to axonal defects. Hum Mol Genet 21:4587-4601. CrossRef Medline

Rosette C, Karin M (1996) Ultraviolet light and osmotic stress: activation of the JNK cascade through multiple growth factor and cytokine receptors. Science 274:1194-1197. CrossRef Medline

Rusu P, Jansen A, Soba P, Kirsch J, Löwer A, Merdes G, Kuan YH, Jung A, Beyreuther K, Kjaerulff O, Kins S (2007) Axonal accumulation of synaptic markers in APP transgenic Drosophila depends on the NPTY motif and is paralleled by defects in synaptic plasticity. Eur J Neurosci 25:10791086. CrossRef Medline

Satpute-Krishnan P, DeGiorgis JA, Conley MP, Jang M, Bearer EL (2006) A peptide zipcode sufficient for anterograde transport within amyloid precursor protein. Proc Natl Acad Sci U S A 103:16532-16537. CrossRef Medline

Scott JN, Parhad IM, Clark AW (1991) Beta-amyloid precursor protein gene is differentially expressed in axotomized sensory and motor systems. Brain Res Mol Brain Res 10:315-325. CrossRef Medline

Sheng JG, Price DL, Koliatsos VE (2003) The beta-amyloid-related proteins presenilin 1 and BACE1 are axonally transported to nerve terminals in the brain. Exp Neurol 184:1053-1057. CrossRef Medline

Shi J, Yang SH, Stubley L, Day AL, Simpkins JW (2000) Hypoperfusion induces overexpression of beta-amyloid precursor protein mRNA in a focal ischemic rodent model. Brain Res 853:1-4. CrossRef Medline

Skovronsky DM, Pijak DS, Doms RW, Lee VM (2000) A distinct ER/IC gamma-secretase competes with the proteasome for cleavage of APP. Biochemistry 39:810-817. CrossRef Medline

Smith DH, Chen XH, Iwata A, Graham DI (2003) Amyloid beta accumulation in axons after traumatic brain injury in humans. J Neurosurg 98: 1072-1077. CrossRef Medline

Somosy Z (2000) Radiation response of cell organelles. Micron 31:165-181. CrossRef Medline

Steuble M, Gerrits B, Ludwig A, Mateos JM, Diep TM, Tagaya M, Stephan A, Schätzle P, Kunz B, Streit P, Sonderegger P (2010) Molecular characterization of a trafficking organelle: dissecting the axonal paths of calsyntenin-1 transport vesicles. Proteomics 10:3775-3788. CrossRef Medline

Steuble M, Diep TM, Schätzle P, Ludwig A, Tagaya M, Kunz B, Sonderegger P (2012) Calsyntenin-1 shelters APP from proteolytic processing during anterograde axonal transport. Biol Open 1:761-774. CrossRef Medline

Stokin GB, Goldstein LS (2006) Axonal transport and Alzheimer's disease. Annu Rev Biochem 75:607-627. CrossRef Medline

Stokin GB, Lillo C, Falzone TL, Brusch RG, Rockenstein E, Mount SL, Raman R, Davies P, Masliah E, Williams DS, Goldstein LS (2005) Axonopathy and transport deficits early in the pathogenesis of Alzheimer's disease. Science 307:1282-1288. CrossRef Medline

Szodorai A, Kuan YH, Hunzelmann S, Engel U, Sakane A, Sasaki T, Takai Y, Kirsch J, Müller U, Beyreuther K, Brady S, Morfini G, Kins S (2009) APP anterograde transport requires Rab3A GTPase activity for assembly of the transport vesicle. J Neurosci 29:14534-14544. CrossRef Medline

Szpankowski L, Encalada SE, Goldstein LS (2012) Subpixel colocalization reveals amyloid precursor protein-dependent kinesin- 1 and dynein association with axonal vesicles. Proc Natl Acad Sci U S A 109:8582-8587. CrossRef Medline

Takamori S, Holt M, Stenius K, Lemke EA, Grønborg M, Riedel D, Urlaub H, Schenck S, Brügger B, Ringler P, Müller SA, Rammner B, Gräter F, Hub JS, De Groot BL, Mieskes G, Moriyama Y, Klingauf J, Grubmüller H, Heuser J, et al. (2006) Molecular anatomy of a trafficking organelle. Cell 127:831-846. CrossRef Medline

Thinakaran G, Koo EH (2008) Amyloid precursor protein trafficking, processing, and function. J Biol Chem 283:29615-29619. CrossRef Medline

Tienari PJ, De Strooper B, Ikonen E, Simons M, Weidemann A, Czech C, Hartmann T, Ida N, Multhaup G, Masters CL, Van Leuven F, Beyreuther K, Dotti CG (1996) The beta-amyloid domain is essential for axonal sorting of amyloid precursor protein. EMBO J 15:5218-5229. Medline

Tokuda T, Kametani F, Tanaka K, Sahara N, Ikeda S, Yanagisawa N (1996) Amyloid beta protein and its 3-kDa fragment are present in the axoplasm fraction of the white matter in human brain. Biochem Biophys Res Commun 223:165-169. CrossRef Medline

Vagnoni A, Perkinton MS, Gray EH, Francis PT, Noble W, Miller CC (2012) Calsyntenin-1 mediates axonal transport of the amyloid precursor protein and regulates $\mathrm{A} \beta$ production. Hum Mol Genet 21:2845-2854. CrossRef Medline

Van den Heuvel C, Blumbergs PC, Finnie JW, Manavis J, Jones NR, Reilly PL, Pereira RA (1999) Upregulation of amyloid precursor protein messenger RNA in response to traumatic brain injury: an ovine head impact model. Exp Neurol 159:441-450. CrossRef Medline

Vogt L, Schrimpf SP, Meskenaite V, Frischknecht R, Kinter J, Leone DP, Ziegler U, Sonderegger P (2001) Calsyntenin-1, a proteolytically processed postsynaptic membrane protein with a cytoplasmic calciumbinding domain. Mol Cell Neurosci 17:151-166. CrossRef Medline

Volknandt W, Karas M (2012) Proteomic analysis of the presynaptic active zone. Exp Brain Res 217:449-461. CrossRef Medline

Weidemann A, König G, Bunke D, Fischer P, Salbaum JM, Masters CL, Beyreuther K (1989) Identification, biogenesis, and localization of precursors of Alzheimer's disease A4 amyloid protein. Cell 57:115-126. CrossRef Medline

Yamazaki T, Koo EH, Selkoe DJ (1996) Trafficking of cell-surface amyloid beta-protein precursor. II. Endocytosis, recycling and lysosomal targeting detected by immunolocalization. J Cell Sci 109:999-1008. Medline

Zhang H, Ma Q, Zhang YW, Xu H (2012) Proteolytic processing of Alzheimer's $\beta$-amyloid precursor protein. J Neurochem 120 [Suppl 1]:9-21. CrossRef Medline 